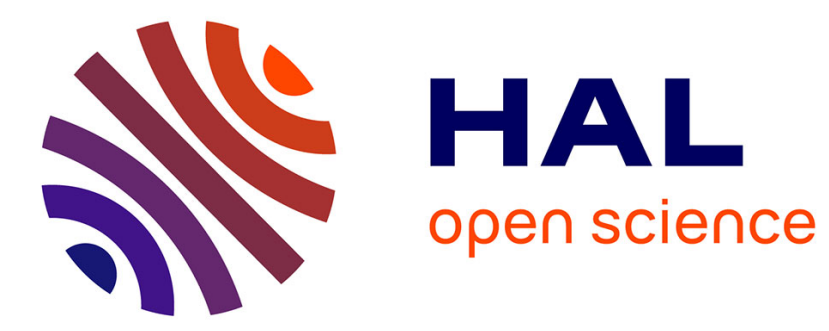

\title{
Mathematical modeling of pulmonary tuberculosis therapy: insights from a prototype model with rifampin
}

Sylvain Goutelle, Laurent Bourguignon, Roger W. Jelliffe, John E. Conte, Pascal Maire

\section{- To cite this version:}

Sylvain Goutelle, Laurent Bourguignon, Roger W. Jelliffe, John E. Conte, Pascal Maire. Mathematical modeling of pulmonary tuberculosis therapy: insights from a prototype model with rifampin. Journal of Theoretical Biology, 2011, 10.1016/j.jtbi.2011.05.013 . hal-00709543

HAL Id: hal-00709543

https://hal.science/hal-00709543

Submitted on 19 Jun 2012

HAL is a multi-disciplinary open access archive for the deposit and dissemination of scientific research documents, whether they are published or not. The documents may come from teaching and research institutions in France or abroad, or from public or private research centers.
L'archive ouverte pluridisciplinaire HAL, est destinée au dépôt et à la diffusion de documents scientifiques de niveau recherche, publiés ou non, émanant des établissements d'enseignement et de recherche français ou étrangers, des laboratoires publics ou privés. 


\section{Author's Accepted Manuscript}

Mathematical modeling of pulmonary tuberculosis therapy: insights from a prototype model with rifampin

Sylvain Goutelle, Laurent Bourguignon, Roger W. Jelliffe, John E. Conte Jr, Pascal Maire
PII:
S0022-5193(11)00255-4
DOI: doi:10.1016/j.jtbi.2011.05.013
Reference: YJTBI 6477

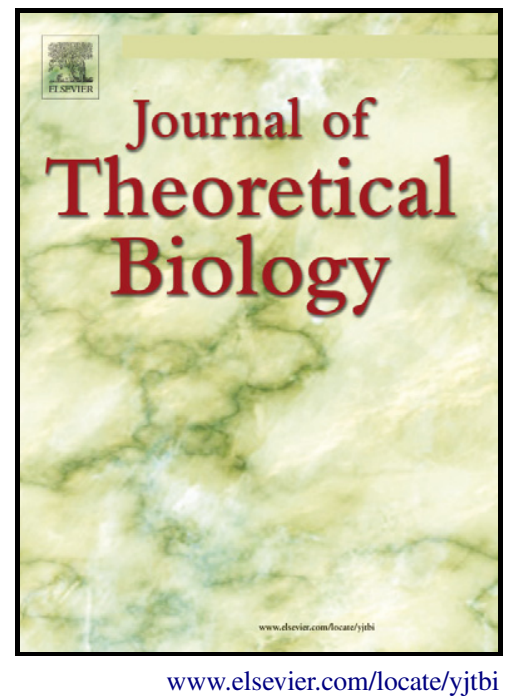

To appear in: $\quad$ Journal of Theoretical Biology

Received date: 12 December 2010

Revised date: $\quad 8$ May 2011

Accepted date: $\quad 10$ May 2011

Cite this article as: Sylvain Goutelle, Laurent Bourguignon, Roger W. Jelliffe, John E. Conte and Pascal Maire, Mathematical modeling of pulmonary tuberculosis therapy: insights from a prototype model with rifampin, Journal of Theoretical Biology, doi:10.1016/j.jtbi.2011.05.013

This is a PDF file of an unedited manuscript that has been accepted for publication. As a service to our customers we are providing this early version of the manuscript. The manuscript will undergo copyediting, typesetting, and review of the resulting galley proof before it is published in its final citable form. Please note that during the production process errors may be discovered which could affect the content, and all legal disclaimers that apply to the journal pertain. 


\section{Mathematical modeling of pulmonary tuberculosis therapy: insights from a prototype} model with rifampin

Sylvain Goutelle ${ }^{1,2}$, Laurent Bourguignon ${ }^{1,2}$, Roger W. Jelliffe ${ }^{3}$, John E. Conte Jr ${ }^{4,5}$, Pascal Maire ${ }^{1,2}$

${ }^{1}$ Hospices Civils de Lyon, Groupement Hospitalier de Gériatrie, Service Pharmaceutique ADCAPT, Francheville, France

${ }^{2}$ Université de Lyon, F-69000, Lyon ; Université Lyon 1 ; CNRS, UMR5558, Laboratoire de Biométrie et Biologie Evolutive, F-69622, Villeurbanne, France

${ }^{3}$ Laboratory of Applied Pharmacokinetics, Keck School of Medicine, University of Southern California, Los Angeles, CA, USA

${ }^{4}$ Department of Epidemiology \& Biostatistics, University of California, San Francisco, San Francisco, CA, USA

${ }^{5}$ American Health Sciences, San Francisco, CA, USA

This work was presented in part as an oral communication at the $19^{\text {th }}$ Population Approach Group in Europe (PAGE) annual meeting in Berlin, 8-11 June 2010.

Corresponding author

Sylvain Goutelle

Hospices Civils de Lyon, Hôpital Pierre Garraud, Service Pharmaceutique, 136 rue du Commandant Charcot 69005 LYON, France

Phone : (+33) 472168099 ; Fax : (+33) 472168102

E-mail : sylvain.goutelle@,chu-lyon.fr 


\section{Abstract}

There is a critical need for improved and shorter tuberculosis (TB) treatment. Current in vitro models of TB, while valuable, are poor predictors of the antibacterial effect of drugs in vivo. Mathematical models may be useful to overcome the limitations of traditional approaches in TB research. The objective of this study was to set up a prototype mathematical model of TB treatment by rifampin, based on pharmacokinetic, pharmacodynamic and disease submodels. The full mathematical model can simulate the time-course of tuberculous disease from the first day of infection to the last day of therapy. Therapeutic simulations were performed with the full model to study the antibacterial effect of various dosage regimens of rifampin in lungs.

The model reproduced some qualitative and quantitative properties of the bactericidal activity of rifampin observed in clinical data. The kill curves simulated with the model showed a typical biphasic decline in the number of extracellular bacteria consistent with observations in TB patients. Simulations performed with more simple pharmacokinetic/pharmacodynamic models indicated a possible role of a protected intracellular bacterial compartment in such a biphasic decline.

This modelling effort strongly suggests that current dosage regimens of RIF may be further optimized. In addition, it suggests a new hypothesis for bacterial persistence during TB treatment. 


\section{Introduction}

Tuberculosis (TB) remains one of the leading causes of death by infectious disease. In 2007, TB was responsible for approximately 1.75 million deaths, including $450000 \mathrm{HIV}$ co-infected people (World Health Organization, 2009). In addition, it is estimated that one third of the world population is latently infected by Mycobacterium tuberculosis.

Despite the clinical effectiveness of well-conducted short-course chemotherapy (Mitchison, 2005), there are several issues associated with current TB treatment. The emergence of multidrug and extensive resistance is a major concern since it might lead to the multiplication of incurable tuberculosis cases (Centers, 2006; Gandhi et al., 2006). Another major problem of current tuberculosis treatment is its duration, which is a minimum of 6 months. Shortening the duration of effective TB therapy should have important benefits, including better patients' compliance and lower rates of default, relapse, and drug resistance. Assuming such potential benefits, a simulation study by Salomon and colleagues showed that a shorter 2 month-treatment could greatly reduce TB mortality and incidence of new cases (Salomon et al., 2006).

Traditional approaches in pre-clinical tuberculosis research are based on in vitro and animal models. Animal models are valuable but expensive and cannot fully emulate the human disease (Gupta and Katoch, 2005). In vitro models provide information on drug potency but they are poorly predictive of the duration and magnitude of drug effect in patients (Burman, 1997; Nuermberger and Grosset, 2004).

Mathematical models may be helpful to represent and study current problems associated with TB treatment, and to suggest innovative approaches (Young et al., 2008). In this report, we present a prototype mathematical model which describes the time-course of both tuberculous infection and its treatment by rifampin in the human lung. The full model 
and simpler pharmacokinetic/pharmacodynamic models were used to simulate the antibacterial effect of various rifampin dosage regimens.

\section{Model description}

The full model was based on three submodels: a pharmacokinetic (PK) model, a pharmacodynamic model (PD), and a disease model (or pathophysiological model).

\subsection{Pharmacokinetic model}

A four-compartment, nine-parameter model was used as the PK model. In a previously published population PK study, this model adequately described plasma, epithelial lining fluid (ELF), and alveolar cell (AC) concentrations from 34 non-infected subjects (Goutelle et al., 2009). The PK model had the following system of ordinary differential equations (ODE):

$$
\begin{aligned}
& d X_{A} / d t=-K_{A} \cdot X_{A} \\
& d X_{1} / d t=K_{A} \cdot X_{A}-K_{E} \cdot X_{1}-K_{12} \cdot X_{1}+K_{21} \cdot X_{2} \\
& d X_{2} / d t=K_{12} \cdot X_{1}-K_{21} \cdot X_{2}-K_{23} \cdot X_{2}+K_{32} \cdot X_{3} \\
& d X_{3} / d t=K_{23} \cdot X_{2}-K_{32} \cdot X_{3}
\end{aligned}
$$

where $X_{A}, X_{1}, X_{2}, X_{3}$ are the amounts of drug in the absorptive (oral depot) compartment, the central (plasma concentration) compartment, the pulmonary epithelial lining fluid (ELF) compartment, and the pulmonary alveolar cell (AC) compartment, respectively (in milligrams). $\mathrm{K}_{\mathrm{A}}\left(\mathrm{h}^{-1}\right)$ is the oral absorptive rate constant. $\mathrm{K}_{\mathrm{E}}\left(\mathrm{h}^{-1}\right)$ is the elimination rate constant from the central compartment, and $\mathrm{K}_{12}, \mathrm{~K}_{21}, \mathrm{~K}_{23}, \mathrm{~K}_{32}$ are the intercompartmental transfer rate constants (all in $\left.\mathrm{h}^{-1}\right)$. 
In addition, three output equations are associated with the above drug amounts, as follows:

$\mathrm{C}_{1}=\mathrm{X}_{1} / \mathrm{V}_{\mathrm{C}}$

$\mathrm{C}_{\mathrm{ELF}}=\mathrm{X}_{2} / \mathrm{V}_{\mathrm{ELF}}$

$\mathrm{C}_{\mathrm{CELL}}=\mathrm{X}_{3} / \mathrm{V}_{\mathrm{CELL}}$

Where $\mathrm{C}_{1}, \mathrm{C}_{\mathrm{ELF}}$ and $\mathrm{C}_{\mathrm{CELL}}$ are rifampin concentrations in the central (plasma) compartment, the ELF compartment, and the AC compartment, respectively (in mg/L). The symbols $\mathrm{V}_{\mathrm{C}}$, $\mathrm{V}_{\mathrm{ELF}}$, and $\mathrm{V}_{\mathrm{CELL}}$ represent the apparent volumes of distribution of the central, ELF and AC compartments, respectively (all in liters).

\subsection{Pharmacodynamic model}

The PD model links rifampin concentration at the effect site with its antibacterial effect.

The effect of rifampin on sensitive bacteria was described by the following equation:

$\frac{d N}{d t}=K_{g \max } N\left(1-\frac{N}{N_{\max }}\right)\left(1-\frac{C^{\alpha_{g}}}{C_{50 g}^{\alpha_{g}}+C^{\alpha_{g}}}\right)-K_{k \max } N \frac{C^{\alpha_{k}}}{C_{50 k}^{\alpha_{k}}+C^{\alpha_{k}}}$

The bacterial dynamics is assumed to result from logistic bacterial growth and drug-mediated killing. The drug also inhibits the bacterial growth, so the antibacterial effect of the drug results from both killing and growth inhibition. In equation (3), $\mathrm{N}$ is the number of bacteria, $\mathrm{K}_{\mathrm{gmax}}$ is the maximum growth rate constant of M. tuberculosis $\left(\right.$ in $\left.^{-1}\right), \mathrm{K}_{\mathrm{kmax}}$ is the maximum kill rate $\left(\mathrm{h}^{-1}\right), \mathrm{N}_{\max }$ is the maximum number of bacteria, $\mathrm{C}$ is the rifampin concentration at the effect site (in mg/L), $\alpha_{g}$ and $\alpha_{k}$ are the Hill coefficients of sigmoidicity for the effect on 
growth and killing, respectively (no units), and $\mathrm{C}_{50 \mathrm{~g}}$ and $\mathrm{C}_{50 \mathrm{k}}$ are the median effect concentrations for the effect on growth and killing, respectively (in $\mathrm{mg} / \mathrm{L}$ ).

This equation was derived from the model used by Gumbo et al. to describe the effect of rifampin and other anti-TB drugs on both drug-sensitive and resistant bacteria in an in vitro hollow-fiber system (Gumbo et al., 2004; Gumbo et al., 2007c). The effect of rifampin on resistant subpopulations of M. tuberculosis was not included in the present model.

\subsection{Tuberculous disease model}

The immune response model published by Kirschner and colleagues was used to simulate bacterial dynamics from the first day of TB infection (Marino and Kirschner, 2004;

Wigginton and Kirschner, 2001).

Briefly, the lung and lymph node model is a system of 17 ODE which describe the timecourse of the human immune response in lung and lymph node during TB infection. In the lung compartment, the variables included are: resident $\left(\mathrm{M}_{R}\right)$, activated $\left(\mathrm{M}_{\mathrm{A}}\right)$, and infected $\left(\mathrm{M}_{\mathrm{I}}\right)$ macrophages; interferon gamma (IFN $\gamma$ ) and interleukins $\mathrm{IL}_{12}, \mathrm{IL}_{10}$, and $\mathrm{IL}_{4}$; Tlymphocyte precursors $\left(\mathrm{Th}_{0}\right), \mathrm{Th}_{1}$, and $\mathrm{Th}_{2}$ lymphocytes; immature dentritic cells (IDC); and extracellular $\left(\mathrm{B}_{\mathrm{E}}\right)$ and intracellular $\left(\mathrm{B}_{\mathrm{I}}\right)$ M. tuberculosis bacilli. For the lymph node compartment, there are four variables: naïve T-cells $(\mathrm{T}), \mathrm{T}$-lymphocyte precursors $\left(\mathrm{Th}_{0 \mathrm{ln}}\right), \mathrm{IL}_{12}$ $\left(\mathrm{IL}_{12 \mathrm{ln}}\right)$, and mature dendritic cells (MDC).

Only our modifications done to the Kirschner's model for the building of the full model will be described in the next pages. Further details on the disease model can be found in the original publications from this group (Marino and Kirschner, 2004; Wigginton and Kirschner, 2001)

\subsection{The final model}


The final full model was built by connecting the PK/PD model of rifampin with the TB disease model from Kirschner and colleagues, resulting in a 21 ODE-system. Actually, only the two equations of the bacterial dynamics were altered in their lung and lymph node model, as shown below. The other 15 equations of this model remained unchanged from the original publication (Marino and Kirschner, 2004). The PD equation was incorporated into the dynamics of the extracellular bacteria $\left(\mathrm{B}_{\mathrm{E}}\right)$ in lungs as follows:

$$
\begin{aligned}
& \frac{d B_{E}}{d t}=K_{g \max (E)} B_{E}\left(1-\frac{B_{E}}{B_{E \max }}\right)\left(1-\frac{C_{E L F}^{\alpha_{g}}}{C_{50 g}^{\alpha_{g}}+C_{E L F}^{\alpha_{g}}}\right)-K_{k \max (E)} B_{E} \frac{C_{E L F}^{\alpha_{k}}}{C_{50 k}^{\alpha_{k}}+C_{E L F} \alpha_{k}} \\
& -k_{15} M_{A} B_{E}-k_{18} M_{R} B_{E}+k_{14} N_{1} M_{I}\left(\frac{T_{T} / M_{I}}{T_{T} / M_{I}+c_{4}}\right) \\
& +k_{17} N M_{I}\left(\frac{B_{I}^{m}}{B_{I}^{m}+\left(N M_{I}\right)^{m}}\right)-k_{2}\left(\frac{N}{2}\right) M_{R}\left(\frac{B_{E}}{B_{E}+c_{9}}\right)-d_{12} B_{E} I D C
\end{aligned}
$$

The dynamics of intracellular bacteria in lungs $\left(\mathrm{B}_{\mathrm{I}}\right)$ was modified as shown below:

$$
\begin{aligned}
& \frac{d B_{I}}{d t}=K_{g \max (I)} B_{I}\left(1-\frac{B_{I}^{m}}{B_{I}^{m}+\left(N M_{I}\right)^{m}}\right)\left(1-\frac{C_{C E L L}^{\alpha_{g}}}{E C_{50 g}^{\alpha_{g}}+C_{C E L L}^{\alpha_{g}}}\right)-K_{k \max (I)} B_{I} \frac{C_{C E L L} \alpha_{k}}{E C_{50 k}^{\alpha_{k}}+C_{C E L L} \alpha_{k}} \\
& -k_{17} N M_{I}\left(\frac{B_{I}^{m}}{B_{I}^{m}+\left(N M_{I}\right)^{m}}\right)+k_{2}\left(\frac{N}{2}\right) M_{R}\left(\frac{B_{E}}{B_{E}+c_{9}}\right) \\
& -k_{14} N_{1} M_{I}\left(\frac{T_{T} / M_{I}}{T_{T} / M_{I}+c_{4}}\right)
\end{aligned}
$$

In the presence of rifampin, we assume that drug concentration in epithelial lining fluid $\left(\mathrm{C}_{\mathrm{ELF}}\right)$ and alveolar cells $\left(\mathrm{C}_{\mathrm{CELL}}\right)$ drive the antibacterial effect of rifampin on extracellular and intracellular M. tuberculosis, respectively. Those concentrations are provided by the PK model. 
When no drug is present ( $\mathrm{C}_{\mathrm{ELF}}$ and $\mathrm{C}_{\mathrm{CELL}}$ are equal to zero), the bacterial dynamics is driven only by the disease model. Both extracellular and intracellular bacterial proliferate (at maximal growth rate $\mathrm{K}_{\operatorname{gmax}(\mathrm{E})}$ and $\mathrm{K}_{\operatorname{gmax}(\mathrm{I})}$, in $\mathrm{h}^{-1}$ ). We assume a logistic growth for $\mathrm{B}_{\mathrm{E}}$, while the intracellular growth is limited by the number of infected macrophages $\left(\mathrm{M}_{\mathrm{I}}\right)$ and the maximal bacterial load $(\mathrm{N})$ of this type of cells (the product $\mathrm{N}^{*} \mathrm{M}_{\mathrm{I}}$ ). Extracellular bacteria are killed by activated $\left(\mathrm{M}_{\mathrm{A}}\right)$ and resident $\left(\mathrm{M}_{\mathrm{R}}\right)$ macrophages (at rate $\mathrm{k}_{15}$ and $\mathrm{k}_{18}\left(\mathrm{~h}^{-1}\right)$, respectively). Extracellular TB bacilli are also captured by immature dendritic cells (IDC), at rate $d_{12}\left(h^{-1}\right)$. Internalization of extracellular bacteria by resident macrophages makes extracellular bacilli become intracellular. It is assumed that this process is saturable, and that a macrophage can carry one-half of its maximal bacterial load $(\mathrm{N})$, and so the maximal rate of internalization is $\mathrm{k}_{2} *(\mathrm{~N} / 2) \mathrm{h}^{-1}$. In return, intracellular bacilli become extracellular because of bursting and apoptosis infected macrophages. These are also considered as saturable processes. Bursting is limited by the carrying capacity of infected macrophages (the maximal rate of bursting is $\mathrm{k}_{17} * \mathrm{~N} * \mathrm{M}_{\mathrm{I}}$, in $\mathrm{h}^{-1}$ ). Macrophage apoptosis is assumed to be driven by the entire $\mathrm{T}$-cell lung population $\left(\mathrm{T}_{\mathrm{T}}\right.$ is the sum of Th precursors, Th1, and Th2 cells in lungs, see (Wigginton and Kirschner, 2001)). It is also assumed that only a fraction of the maximal bacterial load of infected macrophages is released in the extracellular compartment during apoptosis $\left(\mathrm{N}_{1}<\mathrm{N}\right)$. Additional information about the disease model equations and parameters can be found in the original publications from Kirschner's group (Marino and Kirschner, 2004; Wigginton and Kirschner, 2001).

\subsection{Parameter values and simulation settings}

All simulations with the final model were performed using Matlab software (version 6.5, The MathWorks, Natick, MA, USA). The 21 ODE-system was solved by use of the ode15s solver implemented in Matlab. 


\subsubsection{Simulations without any drug}

First, simulations without any drug present were performed to reproduce different TB progression patterns. Tuberculosis latency was simulated using parameter values published by Marino and Kirschner (Marino and Kirschner, 2004) for all the parameters of the disease model, except for the maximal growth rate constant of extracellular bacteria, $\mathrm{K}_{\mathrm{gmax}(\mathrm{E}) \text {, which }}$ was fixed at $0.01 \mathrm{~h}^{-1}$ instead of $0.005 \mathrm{~h}^{-1}$. Initial conditions used for simulations with the disease model are shown in table 1.

Then, we modified the value of the two bacterial growth rate constants in order to simulate the time course of TB active disease. Doubling times reported for extracellular H37Rv $M$. tuberculosis in mice lungs ranged from 17h to $56 \mathrm{~h}$ (Manca et al., 1999; North and Izzo, 1993). For the same strain, in various intracellular conditions, doubling time ranged from about 24 to 80h, approximately (Chanwong et al., 2007; Jayaram et al., 2003; Paul et al., 1996; Silver et al., 1998). Based on those published data, the maximum growth rate constants for extracellular and intracellular bacteria were fixed at $0.03 \mathrm{~h}^{-1}$ (doubling time $=23.1 \mathrm{~h}$ ), and $0.015 \mathrm{~h}^{-1}$ (doubling time $\left.=46.2 \mathrm{~h}\right)$, respectively.

\subsubsection{Simulation of rifampin therapy}

All simulations of rifampin therapy were organized in two successive time periods. In the first period, the model was used to simulate the development of active TB disease, as described above (2.5.1.). In this period, there was no drug administration and so, no drug effect was simulated. Parameter values for the PD equations are shown in table 2. Since all parameters had fixed values, only one trajectory was simulated, as shown in the various relevant figures. In the second period, rifampin therapy was arbitrarily introduced after 6 months, when a high bacterial load had been achieved in lungs. Various rifampin regimens, in terms of duration 
and dose, were simulated. In this period, PK variability was introduced in the modeling framework by using the individual PK parameter values (Bayesian posterior estimates) of the 34 subjects from an earlier PK study (Goutelle et al., 2009). A summary of the individual PK parameter values used in the simulations is presented in table 3 . As a consequence of the PK variability, 34 individual trajectories for $\mathrm{PK}$ and $\mathrm{PD}\left(\mathrm{B}_{\mathrm{E}}\right.$ and $\left.\mathrm{B}_{\mathrm{I}}\right)$ variables may be displayed in period 2 .

\subsection{Simulations with only the PK/PD model}

Simulations with a more simple PK/PD model were also performed. The objective was to examine various hypotheses regarding the shape of the killing effect of rifampin more easily than with the full model. This model only featured the four PK and the two PD equations from the full model, but did not include the equations from the disease model. The PD equations describing the bacterial dynamics were modified as follows:

$$
\begin{aligned}
& \frac{d B_{E}}{d t}=K_{g \max (E)} B_{E}\left(1-\frac{B_{E}}{B_{E \max }}\right)\left(1-\frac{C_{1}^{\alpha_{g}}}{E C_{50 g}^{\alpha_{g}}+C_{1}^{\alpha_{g}}}\right)-K_{k \max (E)} \frac{C_{1}^{\alpha_{k}}}{E C_{50 k}^{\alpha_{k}}+C_{1}^{\alpha_{k}}} \cdot B_{E} \\
& -K_{E I} B_{E}+K_{I E} B_{I}
\end{aligned}
$$

$$
\begin{aligned}
& \frac{d B_{I}}{d t}=K_{g \max (I)} B_{I}\left(1-\frac{B_{I}}{B_{I \max }}\right)\left(1-\frac{C_{2}^{\alpha_{g}}}{E C_{50 g}^{\alpha_{g}}+C_{2}^{\alpha_{g}}}\right)-K_{k \max (I)} \frac{C_{2}^{\alpha_{k}}}{E C_{50 k}^{\alpha_{k}}+C_{2}^{\alpha_{k}}} B_{I} \\
& +K_{E I} B_{E}-K_{I E} B_{I}
\end{aligned}
$$

In this simpler model, we assumed a logistic growth of intracellular bacteria $\left(\mathrm{BI}_{\max }=10^{7}\right.$ bacteria / ml), and first order transfer of bacteria from the extracellular to the intracellular compartment, and vice-versa (at rate $\mathrm{K}_{\mathrm{EI}}$ and $\mathrm{K}_{\mathrm{IE}}$, in $\mathrm{h}^{-1}$ ). As this model can only simulate the rifampin treatment period, we assumed initial conditions of high bacterial load in lungs $\left(\mathrm{B}_{\mathrm{E}}(0)\right.$ 
$=10^{9}$ bacteria $/ \mathrm{ml}$ and $\mathrm{B}_{\mathrm{I}}(0)=10^{7}$ bacteria $\left./ \mathrm{ml}\right)$. The individual Bayesian posterior $\mathrm{PK}$ parameter values of the 34 subjects from the earlier PK study (Goutelle et al., 2009) were used as described above. Other parameter values were the same as described for the simulations with the full model (see 2.5.2. and table 2), unless otherwise specified below.

We compared the antibacterial effect predicted by equation (6) under four parameterizations $(6 \mathrm{a}, 6 \mathrm{~b}, 6 \mathrm{c}$, and $6 \mathrm{~d}$, respectively). For each simulation, the same rifampin dosage regimen was simulated (1200 mg per day for 20 days). Those four simulations reflected different assumptions concerning the effect of rifampin on $M$. tuberculosis extracellular and intracellular populations:

- $\mathrm{k}_{\mathrm{EI}}=\mathrm{k}_{\mathrm{IE}}=0 ; \mathrm{C}_{1}=\mathrm{C}_{\mathrm{ELF}} ; \mathrm{C}_{2}=\mathrm{C}_{\mathrm{CELL}}$

No exchange between $\mathrm{B}_{\mathrm{E}}$ and $\mathrm{B}_{\mathrm{I}}$, specific $\mathrm{PK} / \mathrm{PD}$ parameters in each bacterial compartment

- $\mathrm{k}_{\mathrm{EI}} \neq \mathrm{k}_{\mathrm{IE}} \neq 0 ; \mathrm{C}_{1}=\mathrm{C}_{\mathrm{ELF}} ; \mathrm{C}_{2}=\mathrm{C}_{\mathrm{CELL}}$

Reciprocal transfer between $\mathrm{B}_{\mathrm{E}}$ and $\mathrm{B}_{\mathrm{I}}$, specific $\mathrm{PK} / \mathrm{PD}$ in each bacterial compartment

- $\mathrm{k}_{\mathrm{EI}} \neq \mathrm{k}_{\mathrm{IE}} \neq 0 ; \mathrm{C}_{1}=\mathrm{C}_{2}=\mathrm{C}_{\mathrm{ELF}}$

Reciprocal transfer between $\mathrm{B}_{\mathrm{E}}$ and $\mathrm{B}_{\mathrm{I}}$, same rifampin concentrations in the two compartments, specific PD parameters.

- $\mathrm{k}_{\mathrm{EI}} \neq \mathrm{k}_{\mathrm{IE}} \neq 0 ; \mathrm{C}_{1}=\mathrm{C}_{\mathrm{ELF}} ; \mathrm{C}_{2}=\mathrm{C}_{\mathrm{CELL}} ; \mathrm{K}_{\mathrm{kmax}(\mathrm{I})}=\mathrm{K}_{\mathrm{kmax}(\mathrm{E})}$

Reciprocal transfer between $\mathrm{B}_{\mathrm{E}}$ and $\mathrm{B}_{\mathrm{I}}$, specific $\mathrm{PK}$ in each bacterial compartment, same PD parameters. 
Then, the influence of the transfer rate constants $\mathrm{K}_{\mathrm{EI}}$ and $\mathrm{K}_{\mathrm{IE}}$ on the shape of the antibacterial effect of rifampin was examined using model $6 \mathrm{~b}$, for a 20 -day, $600 \mathrm{mg}$ per day rifampin regimen.

\subsection{Units}

Rifampin concentrations in lungs were measured in milligram per liter $(\mathrm{mg} / \mathrm{L})($ Conte et al., 2004). For the other variables in the lung and lymph node compartments, we assumed that 1 $\mathrm{cm}^{3}=1 \mathrm{~mL}$. All quantities are expressed per $\mathrm{mL}$ of volume.

\subsection{Analysis of the results}

The analysis focused mainly on the bacterial dynamics predicted by the full model and the PK/PD model. Results from simulations of rifampin therapy with the full model were compared with clinical data, the early bactericidal activity (EBA) of rifampin. The EBA is based on the log-count of viable bacilli in sputum samples during the early days of TB treatment with a single drug. It is usually measured over the first two or the first five days of therapy. However, measurements up to 14 days may be performed also; they have been called "extended EBA" (see ((Donald and Diacon, 2008) for further details about the EBA of anti-TB drugs).

An index similar to the EBA was calculated from simulation results as follows: $\log _{10} \mathrm{~B}_{\mathrm{E}}\left(\mathrm{t}_{1}\right)-$ $\log _{10} \mathrm{~B}_{\mathrm{E}}\left(\mathrm{t}_{2}\right) /\left[\mathrm{t}_{2}-\mathrm{t}_{1}\right]$, where $\mathrm{B}_{\mathrm{E}}\left(\mathrm{t}_{1}\right)$ and $\mathrm{B}_{\mathrm{E}}\left(\mathrm{t}_{2}\right)$ are the numbers of extracellular bacteria calculated just before the administration of a rifampin dose, at time $t_{1}$ and $t_{2}$, respectively. The predicted antibacterial activity of rifampin was calculated between day 0 and day 2 , day 0 and day 5 , day 2 and day 5, and between day 2 and day 14, for various rifampin dosage regimens. The 
bactericidal activities were compared with published values of EBA calculated for the same time interval.

\section{Results}

\subsection{Simulations with no drug}

\subsubsection{Latent tuberculosis}

The dynamics of extracellular and intracellular bacteria during latent tuberculosis simulated by the full model are shown in figure 1. Intracellular bacteria constitute the predominant population during latent tuberculosis, while the multiplication of extracellular bacilli is contained by the immune response. Figure 2 represents the dynamics of the different populations of pulmonary macrophages and dendritic cells. Those profiles show good agreement with those from Kirschner and colleagues (Marino and Kirschner, 2004). The bacterial dynamics are somewhat slower, the number of extracellular bacteria reaching its maximum on day 300 approximately, instead of day 200 in their simulation of latency, and the late rebound of extracellular bacteria observed after day 1500 seems to be greater. Overall, the bacterial and cellular populations reach latency levels comparable to those presented in the original publication.

\subsubsection{Active disease}

The evolution of the bacterial populations during active tuberculosis is shown in figure 3 . Compared with bacterial profiles of latent tuberculosis (figure 1), a much higher bacterial load is achieved, and extracellular bacilli represent the predominant population. The dynamics of 
macrophages and dendritic cells are shown in figure 4A and 4B, respectively. Compared with latent TB, active disease is characterized by higher levels of infected macrophages (MI) and mature dendritic cells (MDC). Of note, those profiles of active tuberculosis do not represent a late reactivation of $\mathrm{TB}$, but rather primary $\mathrm{TB}$ without an initial phase of latency.

Again, these profiles show good agreement with the original results from Kirschner's group. The bacterial populations $\left(\mathrm{B}_{\mathrm{E}}\right.$ and $\left.\mathrm{B}_{\mathrm{I}}\right)$ reach their maximum density after about 180 days, which is earlier than in published results with the lung and lymph node model (400 days) (Marino and Kirschner, 2004), but close to results from the original lung model (150 days) (Wigginton and Kirschner, 2001).

\subsection{Therapeutic simulations}

\subsubsection{Effect of rifampin therapy}

The evolution of the number of bacteria in lungs during active tuberculosis followed by a 2month treatment with rifampin is depicted in figures 5A and 5B. One can visualize the two periods of time in the modeling framework. From day 0 to day 180 , there is only one trajectory, since only the disease model drives the dynamics, with all parameter having fixed values. The second period starts when rifampin is introduced on day 180 , with a $600 \mathrm{mg}$ oral dose administered every 24 hours, during 60 days. The use of each of the 34 subject's individual PK parameter values in the simulations results in variable drug exposure and drug effect. The individual curves for $B_{E}$ and $B_{I}$ observed after day 180 in figures $5 \mathrm{~A}$ and $5 \mathrm{~B}$ show the considerable effect of pharmacokinetic variability upon the bacterial dynamics during rifampin therapy. For the same rifampin dosage regimen, there was almost no antibacterial 
effect for some subjects, while a sharp decline in the number of $B_{E}$ and $B_{I}$ was observed for others. In most individual profiles of extracellular bacteria, same oscillations are observed. These result from the variation of individual rifampin exposure over the 24-hour dose interval. The simulated PK profiles of the 34 subjects in plasma and lungs over only the first three days of rifampin therapy are shown in figures $6 \mathrm{~A}$ and $6 \mathrm{~B}$, respectively.

In addition, the model was used to study the effect of the rifampin dose size upon the bacterial dynamics. Three rifampin doses were simulated: a $300 \mathrm{mg}$, a standard $600 \mathrm{mg}$, and a $1200 \mathrm{mg}$ dose, all administered as a once daily regimen for 2 months. For this simulation, only the median value of the individual pharmacokinetic parameters was used (see table 3 ). The results are shown in figure 7. With this set of PK parameters, the $300 \mathrm{mg}$ dose was associated with very little reduction in bacterial load. The effect of the $600 \mathrm{mg}$ dose was greater, as expected, but the model predicted that, after an initial phase of decline, the intracellular and extracellular bacterial levels remained stable at a high level after 2 months of therapy. In contrast, the $1200 \mathrm{mg}$ dose produced rapid and complete elimination of intracellular bacilli, and a continuous, large decrease in the number of extracellular bacteria over the 2 months of rifampin treatment.

\subsubsection{Exploration of the antibacterial effect of rifampin on extracellular bacteria}

The qualitative and quantitative properties of the antibacterial effect of rifampin on the extracellular population of M. tuberculosis over the first two weeks of therapy were studied with the full model, for the three rifampin daily doses that have been used in clinical studies: $300 \mathrm{mg}, 600 \mathrm{mg}$, and $1200 \mathrm{mg}$. 
For the first two weeks of therapy, the individual kinetic profiles calculated with the 34 subject dataset are presented in figure 8 . For the standard $600 \mathrm{mg}$ dose, a biphasic shape was observed for some profiles corresponding to the highest bactericidal effects. An initial phase of fast killing was observed, followed by a second phase of slower kill. The second phase started somewhere between day 3 and day 10. This biphasic shape was much less apparent with the lower dose of $300 \mathrm{mg}$, except for the highest antibacterial effect profiles. For the $1200 \mathrm{mg}$ dose, the biphasic killing effect was clearly observed in most profiles, including the median for which the killing slowed down on days 4-5.

The bactericidal activities of rifampin on extracellular bacteria simulated by the full model over the early days of therapy were compared with published data of EBA. Simulated data were calculated for the 34 subjects (PK data set) and for the three dosage regimens of rifampin. The results are presented in table 4 . Overall results from the simulations indicated a decline of the initial bactericidal activity over the first 14 days of rifampin therapy. The bactericidal activities calculated between day 0 and day 2 were greater than the activities calculated between day 2 and day 14. This result is in accordance with data from EBA studies. For the $300 \mathrm{mg}$ dose, bactericidal activities from the full model were similar to EBA data for all periods over the first two weeks. For the standard $600 \mathrm{mg}$ dose, the activity calculated between day 0 and $2(0.277 \pm 0.229)$ was in the range of published data of $\mathrm{EBA}_{0-2}$, which has been the most extensively studied measure. Activities predicted for the other timeperiods were greater than the published results. For the $1200 \mathrm{mg}$ dose, the predicted results were significantly greater than published EBA data. However, very few studies have evaluated such a dose in actual clinical practice.

Finally, the study of the antibacterial effect of rifampin on extracellular bacteria simulated with the full model provided three main results. First, the bactericidal effect showed biphasic kinetics. Second, this biphasic behavior was dose-dependent. The greater the dose, the greater 
the bend in the response. Those two results are in agreement with clinical data of rifampin effect, as illustrated by figure 9 . Third, while the model provided realistic values for the antibacterial effect of low and standard rifampin doses, it seemed to overestimate the effect of large rifampin doses.

\subsection{Simulations with the PK/PD model}

The bacterial dynamics simulated with the four variants of the PK/PD model (equation 6) are shown in figure 10. The regimen simulated was $1200 \mathrm{mg} /$ day during 20 days. For model $6 \mathrm{~b}$, $6 \mathrm{c}$, and $6 \mathrm{~d}$, the values of the transfer constants $\mathrm{K}_{\mathrm{EI}}$ and $\mathrm{K}_{\mathrm{IE}}$ were fixed at $0.001 \mathrm{~h}^{-1}$ and 0.0005

$\mathrm{h}^{-1}$, respectively. Profiles obtained with model $6 \mathrm{a}$, which did not include a transfer between extracellular and intracellular bacterial populations, showed a one-phase, steady decline of both $\mathrm{B}_{\mathrm{E}}$ and $\mathrm{B}_{\mathrm{I}}$, with a slower kill for the latter. Results from model $6 \mathrm{~b}$, which incorporated reciprocal transfer between $\mathrm{B}_{\mathrm{E}}$ and $\mathrm{B}_{\mathrm{I}}$, were characterized by a biphasic decline of $\mathrm{B}_{\mathrm{E}}$, the second phase of slower kill starting about day 5. In addition, the killing of $\mathrm{B}_{\mathrm{I}}$ was slower than observed with model $6 a$. Model $6 \mathrm{c}$ was similar to equation $6 \mathrm{~b}$, except that rifampin concentrations in the two bacterial compartments were set equal to the concentration in the ELF, and so concentrations in the intracellular compartment were lower. Compared with profiles from model $6 \mathrm{~b}$, those from equation $6 \mathrm{c}$ showed comparable shape of the antibacterial effect of rifampin on $B_{E}$ and $B_{I}$. However, killing of $B_{I}$ was slower, while killing of $B_{E}$ was essentially similar during the first phase, and slower in the second phase. Model $6 \mathrm{~d}$ was also a variant of equation $6 \mathrm{~b}$, with the same PD parameters in the extracellular and intracellular bacterial compartments. The profiles associated with model $6 \mathrm{~d}$ were characterized by a monophasic decline of $\mathrm{B}_{\mathrm{E}}$ (a little bit slower than observed with model $6 \mathrm{a}$ ), and a fast monophasic decrease of $\mathrm{B}_{\mathrm{I}}$, basically parallel to $\mathrm{B}_{\mathrm{E}}$. 
Of note, the kinetics of $B_{E}$ simulated with the four variants of equation 6 were identical during the early 5-6 day long phase.

Then, model $6 \mathrm{~b}$ was used to assess the influence of the transfer rate constants between the extracellular and the intracellular bacterial populations on the early antibacterial effect. Figure 11 shows the effect of the $\mathrm{K}_{\mathrm{EI}}$ value on the dynamics of $\mathrm{B}_{\mathrm{E}}$ and $\mathrm{B}_{\mathrm{I}}$ over the first 20 days of rifampin therapy (600 mg / day). The biphasic decline of extracellular bacteria was more pronounced when $\mathrm{K}_{\mathrm{EI}}$ value was greater. For the intracellular bacterial population, an initial increase in the number of bacteria was observed; the higher $\mathrm{K}_{\mathrm{EI}}$ value, the greater it was. This early rise was followed by a slow decline of BI, with no specific shape.

The effect of $\mathrm{K}_{\mathrm{IE}}$ value on the bacterial dynamics is depicted in figure 12. As expected, increasing $\mathrm{K}_{\mathrm{IE}}$ values resulted in a faster decline of the number of intracellular bacteria. For the extracellular bacterial population, a biphasic decline was observed for intermediate values of $\mathrm{K}_{\mathrm{IE}}\left(0.005\right.$ and $\left.0.0005 \mathrm{~h}^{-1}\right)$, but it was not seen for the lowest $\left(0.00005 \mathrm{~h}^{-1}\right)$ and the highest $\left(0.05 \mathrm{~h}^{-1}\right)$ values in the 20 -day therapy simulation. However, when the simulation was performed for a longer therapy, a slower killing phase was observed with $\mathrm{K}_{\mathrm{IE}}=0.00005 \mathrm{~h}^{-1}$ after 20 days, but not with the highest value (data not shown).

In those two simulations, the typical biphasic kinetics of the antibacterial effect of rifampin on extracellular bacteria was observed for $\mathrm{K}_{\mathrm{EI}} / \mathrm{K}_{\mathrm{IE}}$ ratio values ranging from 0.2 and 200. It was not observed for $\mathrm{K}_{\mathrm{EI}} / \mathrm{K}_{\mathrm{IE}}=0.02$ and $\mathrm{KIE}=0.05 \mathrm{~h}^{-1}$, which reflect very fast transfer of bacteria from the intracellular to the extracellular compartment.

In the therapeutic simulations performed with variants of the PK/PD model (equation 6), we identified three conditions associated with the observation of a biphasic antibacterial effect of rifampin on M. tuberculosis: 
- reciprocal transfer between intracellular and extracellular bacterial populations

- slow transfer of bacteria from intracellular to the extracellular compartment

- drug less effective in the intracellular than in the extracellular compartment. 


\section{Discussion}

Tuberculosis infection is characterized by a dynamic equilibrium between the development of the pathogen and the host response. After primary infection by Mycobacterium tuberculosis, the human immune response is able to contain the multiplication of the bacteria in most patients, and the infection may remain clinically silent for decades.

Systems biology is a promising tool to study the complex interactions that exist between the host and the pathogen in persistent infections (Kirschner et al., 2010; Young et al., 2008). In the last 15 years, mathematical models have provided major insights in the knowledge of tuberculosis pathogenesis and human immune response to TB (Fang et al., 2009; Marino et al., 2010; Segovia-Juarez et al., 2004; Wigginton and Kirschner, 2001). In the meantime, progress has been made in the quantitative description of both pharmacokinetics and in vitro pharmacodynamics of antituberculosis drugs (Gumbo, 2010; Gumbo et al., 2007a; Gumbo et al., 2007c; Jayaram et al., 2003; Jayaram et al., 2004; Peloquin et al., 1997).

The objective of the present work was to build and study a prototype mathematical model of TB treatment. Because of the major role of the immune response in the bacterial dynamics and the global clearance of M. tuberculosis, our modeling approach was based on quantitative relationships from both $\mathrm{PK} / \mathrm{PD}$ and systems biology of $\mathrm{TB}$. This construction was possible because current PK/PD models and immune response models at the cell population level both have ODE-based structures.

The full model was able to simulate the bacterial dynamics from the first day of infection to the last day of the treatment by rifampin. Therapeutic simulations showed a considerable contribution of PK variability to the antibacterial effect of rifampin. For the same rifampin dose, the model predicted fast eradication of M. tuberculosis in some subjects, and almost no effect on the bacterial load in others. This is in agreement with clinical observations, as large variations of the EBA of rifampin have been reported (Donald and Diacon, 2008). 
Our simulations also showed that rifampin doses higher than the current standard $600 \mathrm{mg}$ dose would result in a significantly greater antibacterial effect (see figure 7). Previous works have also suggested that the standard rifampin dose is probably suboptimal (Diacon et al., 2007; Goutelle et al., 2009; Gumbo et al., 2007c; Jayaram et al., 2003; Peloquin, 2003). This means that many patients treated with the standard $600 \mathrm{mg} /$ day rifampin dose may be undertreated. As the standard TB chemotherapy based on a combination of four drugs is effective in most patients, one may assume that the effect of the other drugs compensates for rifampin underdosing. However, optimal dosing of rifampin may be beneficial for many TB patients, with more rapid sputum conversion and shorter TB therapy. Further research is necessary to confirm this hypothesis.

The model was used to analyse in detail the qualitative and quantitative properties of the antibacterial effect of rifampin on extracellular bacteria over the first days of therapy. Interestingly, the model reproduced the biphasic decline in the number of bacteria that has been observed in clinical studies (Davies, 2010). An initial phase of rapid killing in the first 25 days was seen, followed by a slower killing phase over approximately the next ten days. This phenomenon appeared to be dose-dependant in our simulations. This is also in accordance with published results (Mitchison, 1996; Mitchison, 2005). From a quantitative point of view, the model also provided some realistic results. The bactericidal activities calculated for the first days of rifampin therapy were comparable to early bactericidal activities reported in the litterature for the $300 \mathrm{mg}$ and the $600 \mathrm{mg}$ dose. However, the model seemed to oyerestimate the effect of higher rifampin doses $(1200 \mathrm{mg})$. This may be due to several limitations of this modelling approach. First, we assumed linear pharmacokinetics of rifampin over the dose range studied. As several studies which compared different rifampin doses reported nonlinear pharmacokinetics in plasma, this might be oversimplistic (Diacon et al., 2007; Pargal and Rani, 2001; Ruslami et al., 2007). The pulmonary pharmacokinetic 
submodel was based on data from subjects who received only $600 \mathrm{mg}$ per day of rifampin. A study on the pulmonary pharmacokinetics of high-dose rifampin would be necessary to clarify this point. Then, this overestimation of the effect of the $1200 \mathrm{mg}$ dose may be due to the nature of the EBA data. The model simulates the number of bacteria in lungs, while EBA is based on the counts of viable bacteria in sputum. Those measurements are likely to underestimate the total bacterial load in the lungs. This may explain such difference between model predictions and clinical data. Alternatively, the larger effect predicted by the model may be questioned. In the Hill equation-based PK/PD model, for the same parameter values, a higher dose $(1200 \mathrm{mg})$ results in a higher effect, closer to the maximum effect. It is possible that the maximum killing effect $\left(\mathrm{K}_{\mathrm{kmax}(\mathrm{E})}\right)$ value used in the model, which is based on in vitro experiments (Jayaram et al., 2003), may overestimate the maximal effect that can be reached in the organism.

In addition, we studied the antibacterial effect of rifampin predicted by much simpler PK/PD models, without the equations describing the immune response. For the same rifampin dose, simulations with PK/PD models that did not include a reciprocal transfer between extracellular and intracellular bacteria showed an antibacterial effect on BE faster than with the full model, and with no biphasic shape. The characteristic biphasic decline of BE was observed with equations that included an exchange between BE and BI populations. To date, the interpretation of the biphasic kinetic clearance of tuberculosis bacilli during TB treatment remains unclear. This has been the subject of an interesting debate in the specialized literature after the publication of a recent work by Gumbo and colleagues on isoniazid (Gumbo et al., 2007b; Mitchison et al., 2007; Wallis et al., 2007). Results from in vitro experiments performed with isoniazid, and also previously with moxifloxacin and ciprofloxacin (Gumbo et al., 2005; Gumbo et al., 2004), suggest that the cessation of the bactericidal activities of those drugs after a few days of therapy may be due to the emergence 
of a resistant subpopulation of M. tuberculosis. Other scientists have argued that those results, obtained in in vitro studies using a single drug, cannot explain the loss of activity of anti-TB drugs observed in patients treated with multiple drugs for which the bacterial sensitivity was controlled by laboratory tests (Wallis et al., 2007). Those authors support the classical "special populations" hypothesis to explain clinical data. This hypothesis is depicted in figure 13. It is thought that different populations of bacilli might exist in TB lesions, including both multiplying bacteria and persistent/dormant bacteria characterized by a slower rate of metabolism and growth and occasional spurts of metabolism. The first phase observed in EBA data would reflect the killing of multiplicative bacilli, and the second phase the killing of persistent bacilli (Mitchison, 1979; Mitchison, 2005). The existence of subpopulations of bacilli has been the most popular hypothesis to explain both the dynamics of M. tuberculosis during latent $\mathrm{TB}$ and its persistence during anti-TB treatment. Experiments performed on Escherichia coli have provided evidence of the existence of bacterial persisters during antibiotic therapy (Balaban et al., 2004; Connolly et al., 2007; Keren et al., 2004). However, little is known about the real nature, location, and biology of possible persistent bacilli in tuberculosis infection (Ehlers, 2009).

To summarize, two major hypotheses have been proposed so far to explain the loss of bactericidal activity of anti-TB drugs in the early days of treatment: genetic resistance and phenotypic persistence. Results from our modeling approach eventually suggest a new hypothesis. A biphasic decline of extracellular bacteria during rifampin treatment was observed in the simulations performed with the full model and the variants of the PK/PD model without any assumption of a resistant or metabolically persistent subpopulation. Only two populations were considered in our models: the extracellular and the intracellular bacteria. Based on our simulations with the PK/PD model variants, we hypothesize that this dual location of M. tuberculosis may be principal major cause of this typical shape of the 
antibacterial effect of anti-TB drugs, and that the intracellular population may constitute a bacterial reservoir. The extracellular bacterial dynamics simulated with the PK/PD models, as presented in figure 10, is illustrative. The initial phase, which is similar with the four models, may reflect "pure" extracellular killing. The bactericidal effect upon the extracellular bacteria does not slow when there is no exchange between the two populations of bacilli, or when rifampin has the same efficacy in both compartments. Otherwise, the intracellular bacterial load appears to be the limiting factor for further killing of extracellular bacteria in the second phase.

Our hypothesis is supported by data from other intracellular pathogens, such as viruses. The kinetic clearance of hepatitis $\mathrm{B}$ or $\mathrm{C}$ virus during antiviral therapy also shows a typical biphasic shape. It is thought that the initial rapid decline may reflect the clearance of plasma virions, while the slower second phase may represent the rate-limiting process of the clearance of infected cells (Bonhoeffer et al., 1997; Lewin et al., 2001; Neumann et al., 1998; Tsiang et al., 1999).

In addition, our simulations have shown that exchange between intracellular and extracellular bacilli, slow transfer of bacteria from intracellular to the extracellular compartment, and lower ability to kill intracellular bacilli may well be key elements in the existence and maintenance of an intracellular reservoir of bacteria.

Previous theoretical works have considered the role of a "protected compartment", or a "refuge", in the long-term persistence of M. tuberculosis and the bacterial dynamics during TB therapy (Antia et al., 1996; Lipsitch and Levin, 1998). However, those studies did not suggest a clear identification of such a protected compartment, and they did not consider its importance for the interpretation of clinical data.

Of note, the hypothesis of an intracellular bacterial reservoir does not reject the role of genetic resistance and metabolic persistence in the dynamics of M. tuberculosis. It is possible that the 
three phenomena co-exist in infected patients. While further research is necessary to confirm these findings, the importance of the intracellular bacterial compartment might have major implications for research concerning new anti-TB drugs. High cellular diffusion and potent intracellular killing effect could be important properties for new drug candidates.

This study has many limitations that should be considered in the interpretation of the results. The construction of the full model was based on pre-existing submodels. The parameter values of the immune response model, as well as those of the pharmacodynamic model, are based on many heterogeneous experimental data. In addition, the PK model was based on data from non-infected subjects (Conte et al., 2004). The intrapulmonary pharmacokinetics of rifampin may be different in TB infected patients, because of the specific pulmonary lesions. As a result, extrapolation of our model results to the human disease remains hypothetical. We only studied the role of pharmacokinetic variability in the antibacterial effect of rifampin. It would be interesting to study the influence of other sources of variability (for example pharmacodynamic or physiological variability) on the results.

In addition, it is clear that the assumptions embodied in this prototype model represent a considerable simplification of the dynamics of real TB infection and therapy.

The present model only includes one antituberculosis drug, while TB therapy always consists of a combination of several drugs. The incorporation of more than one drug in the model will require additional modeling of the combined action of drugs. Except for a recent study on this subject (Drusano et al., 2010), little information is available to date. There is a need for work in population $\mathrm{PK} / \mathrm{PD}$ modelling of combination drug therapy in TB patients.

We also assumed that rifampin exerts its action only by killing and inhibiting the growth of M. tuberculosis. This might be overly simplistic. The mathematical model of tuberculosis therapy from Magombedze and colleagues hypothesized a more complex action of rifampin, 
including a modification of the immune response by the drugs (Magombedze et al., 2006). However, strong evidence of immunomodulation properties of rifampin is still lacking (Jaffuel et al., 1999; Tauber and Nau, 2008). Further research is necessary to clarify this question.

We did not incorporate resistant subpopulations of bacilli in the model. Drug resistance is a major concern for TB control, and various studies have shown that drug resistance may play a key role in the bacterial dynamics during TB therapy (Gumbo et al., 2007b; Lipsitch and Levin, 1998). Some other important characteristics of the pharmacokinetics and pharmacodynamics of rifampin were not included in this prototype model, such as rifampin auto-induction, or post antibiotic effect. As a long post-antibiotic effect of rifampin has been reported (Chan et al., 2001; Gumbo et al., 2007c), it could explain the clinical efficacy of extended-interval rifampin dosage regimens. All these limitations should be considered for future development of this modeling approach.

To conclude, a mathematical model has been built which describes the time-course of TB disease and its treatment, from the first day of infection to the last day of therapy. The model reproduces some important characteristics of the antibacterial effect of rifampin observed in patients. Simulations have shown that the intracellular population of M. tuberculosis may play a major role in the early loss of bactericidal activity observed in clinical practice. Further experimental and clinical studies are required to evaluate these results. However, by suggesting new hypotheses and experiments, this work confirms the utility of mathematical modeling in TB research. 


\section{Acknowledgements}

We thank Dr Gérard Carret, from Laboratoire de Bactériologie, Centre Hospitalier Lyon Sud,

Hospices Civils de Lyon and Université Lyon 1, UMR CNRS 5558 \& Faculté de Médecine

Lyon Sud for his helpful suggestions during the preparation of the manuscript.

\section{Conflicts of interest statement}

The authors have no conflicts of interest.

\section{References}

Allen, B.W., and Mitchison, D.A., 1992. Counts of viable tubercle bacilli in sputum related to smear and culture gradings. Med Lab Sci 49, 94-8.

Antia, R., Koella, J.C., and Perrot, V., 1996. Models of the within-host dynamics of persistent mycobacterial infections. Proc R Soc Lond B 263, 257-263.

Balaban, N.Q., Merrin, J., Chait, R., Kowalik, L., and Leibler, S., 2004. Bacterial persistence as a phenotypic switch. Science 305, 1622-5.

Bonhoeffer, S., May, R.M., Shaw, G.M., and Nowak, M.A., 1997. Virus dynamics and drug therapy. Proc Natl Acad Sci U S A 94, 6971-6.

Burman, W.J., 1997. The value of in vitro drug activity and pharmacokinetics in predicting the effectiveness of antimycobacterial therapy : a critical review. Am J Med Sci 313, 355-363.

Centers, D.C.a.P., 2006. Emergence of Mycobacterium tuberculosis with extensive resistance to second-line drugs. MMWR Morb Mortal Wkly Rep 55, 301-305.

Chan, C.Y., Au-Yeang, C., Yew, W.W., Hui, M., and Cheng, A.F., 2001. Postantibiotic effects of antituberculosis agents alone and in combination. Antimicrob Agents Chemother 45, 3631-4.

Chan, S.L., Yew, W.W., Ma, W.K., Girling, D.J., Aber, V.R., Felmingham, D., Allen, B.W., and Mitchison, D.A., 1992. The early bactericidal activity of rifabutin measured by sputum viable counts in Hong Kong patients with pulmonary tuberculosis. Tuber Lung Dis $73,33-8$.

Chanwong, S., Maneekarn, N., Makonkawkeyoon, L., and Makonkawkeyoon, S., 2007. Intracellular growth and drug susceptibility of Mycobacterium tuberculosis in macrophages. Tuberculosis (Edinb) 87, 130-3.

Connolly, L.E., Edelstein, P.H., and Ramakrishnan, L., 2007. Why is long-term therapy required to cure tuberculosis? PLoS Med 4, e120.

Conte, J.E., Golden, J.A., Kipps, J.E., Lin, E.T., and Zurlinden, E., 2004. Effect of sex and AIDS status on the plasma and intrapulmonary pharmacokinetics of rifampicin. Clin Pharmacokinet 43, 395-404.

Davies, G.R., 2010. Early clinical development of anti-tuberculosis drugs: science, statistics and sterilizing activity. Tuberculosis (Edinb) 90, 171-6. 
Davies, G.R., Brindle, R., Khoo, S.H., and Aarons, L.J., 2006. Use of nonlinear mixed-effects analysis for improved precision of early pharmacodynamic measures in tuberculosis treatment. Antimicrob Agents Chemother 50, 3154-6.

Diacon, A.H., Patientia, R.F., Venter, A., van Helden, P.D., Smith, P.J., McIlleron, H., Maritz, J.S., and Donald, P.R., 2007. Early bactericidal activity of high-dose rifampin in patients with pulmonary tuberculosis evidenced by positive sputum smears. Antimicrob Agents Chemother 51, 2994-6.

Donald, P.R., and Diacon, A.H., 2008. The early bactericidal activity of anti-tuberculosis drugs: a literature review. Tuberculosis (Edinb) 88 Suppl 1, S75-83.

Drusano, G.L., Sgambati, N., Eichas, A., Brown, D.L., Kulawy, R., and Louie, A., 2010. The Combination of Rifampin plus Moxifloxacin Is Synergistic for Suppression of Resistance but Antagonistic for Cell Kill of Mycobacterium tuberculosis as Determined in a Hollow-Fiber Infection Model. MBio 1.

Ehlers, S., 2009. Lazy, dynamic or minimally recrudescent? On the elusive nature and location of the mycobacterium responsible for latent tuberculosis. Infection 37, 87-95.

Fang, X., Wallqvist, A., and Reifman, J., 2009. A systems biology framework for modeling metabolic enzyme inhibition of Mycobacterium tuberculosis. BMC Syst Biol 3, 92.

Gandhi, N.R., Moll, A., Sturm, A.W., Pawinski, R., Govender, T., Lalloo, U., Zeller, K., Andrews, J., and Friedland, G., 2006. Extensively drug-resistant tuberculosis as a cause of death in patients co-infected with tuberculosis and HIV in a rural area of South Africa. Lancet 368, 1575-80.

Gosling, R.D., Uiso, L.O., Sam, N.E., Bongard, E., Kanduma, E.G., Nyindo, M., Morris, R.W., and Gillespie, S.H., 2003. The bactericidal activity of moxifloxacin in patients with pulmonary tuberculosis. Am J Respir Crit Care Med 168, 1342-5.

Goutelle, S., Bourguignon, L., Maire, P.H., Van Guilder, M., Conte, J.E., Jr., and Jelliffe, R.W., 2009. Population modeling and Monte Carlo simulation study of the pharmacokinetics and antituberculosis pharmacodynamics of rifampin in lungs. Antimicrob Agents Chemother 53, 2974-81.

Gumbo, T., 2010. New susceptibility breakpoints for first-line antituberculosis drugs based on antimicrobial pharmacokinetic/pharmacodynamic science and population pharmacokinetic variability. Antimicrob Agents Chemother 54, 1484-91.

Gumbo, T., Louie, A., Deziel, M.R., and Drusano, G.L., 2005. Pharmacodynamic evidence that ciprofloxacin failure against tuberculosis is not due to poor microbial kill but to rapid emergence of resistance. Antimicrob Agents Chemother 49, 3178-81.

Gumbo, T., Louie, A., Deziel, M.R., Parsons, L.M., Salfinger, M., and Drusano, G.L., 2004. Selection of a moxifloxacin dose that suppresses drug resistance in Mycobacterium tuberculosis, by use of an in vitro pharmacodynamic infection model and mathematical modeling. J Infect Dis 190, 1642-51.

Gumbo, T., Louie, A., Liu, W., Brown, D., Ambrose, P.G., Bhavnani, S.M., and Drusano, G.L., 2007a. Isoniazid bactericidal activity and resistance emergence: integrating pharmacodynamics and pharmacogenomics to predict efficacy in different ethnic populations. Antimicrob Agents Chemother 51, 2329-36.

Gumbo, T., Louie, A., Liu, W., Ambrose, P.G., Bhavnani, S.M., Brown, D., and Drusano, G.L., 2007b. Isoniazid's bactericidal activity ceases because of the emergence of resistance, not depletion of Mycobacterium tuberculosis in the log phase of growth. J Infect Dis 195, 194-201.

Gumbo, T., Louie, A., Deziel, M.R., Liu, W., Parsons, L.M., Salfinger, M., and Drusano, G.L., 2007c. Concentration-dependent Mycobacterium tuberculosis killing and prevention of resistance by rifampin. Antimicrob Agents Chemother 51, 3781-8. 
Gupta, U.D., and Katoch, V.M., 2005. Animal models of tuberculosis. Tuberculosis (Edinb) 85, 277-293.

Jaffuel, D., Demoly, P., Gougat, C., Mautino, G., Bousquet, J., and Mathieu, M., 1999. Rifampicin is not an activator of the glucocorticoid receptor in A549 human alveolar cells. Mol Pharmacol 55, 841-6.

Jayaram, R., Gaonkar, S., Kaur, P., Suresh, B.L., Mahesh, B.N., Jayashree, R., Nandi, V., Bharat, S., Shandil, R.K., Kantharaj, E., and Balasubramanian, V., 2003. Pharmacokinetics-pharmacodynamics of rifampin in an aerosol infection model of tuberculosis. Antimicrob Agents Chemother 47, 2118-24.

Jayaram, R., Shandil, R.K., Gaonkar, S., Kaur, P., Suresh, B.L., Mahesh, B.N., Jayashree, R., Nandi, V., Bharath, S., Kantharaj, E., and Balasubramanian, V., 2004. Isoniazid pharmacokinetics-pharmacodynamics in an aerosol infection model of tuberculosis. Antimicrob Agents Chemother 48, 2951-7.

Jindani, A., Dore, C.J., and Mitchison, D.A., 2003. Bactericidal and sterilizing activities of antituberculosis drugs during the first 14 days. Am J Respir Crit Care Med 167, 134854.

Jindani, A., Aber, V.R., Edwards, E.A., and Mitchison, D.A., 1980. The early bactericidal activity of drugs in patients with pulmonary tuberculosis. Am Rev Respir Dis 121, 939-49.

Keren, I., Shah, D., Spoering, A., Kaldalu, N., and Lewis, K., 2004. Specialized persister cells and the mechanism of multidrug tolerance in Escherichia coli. J Bacteriol 186, 817280 .

Kirschner, D.E., Young, D., and Flynn, J.L., 2010. Tuberculosis: global approaches to a global disease. Curr Opin Biotechnol 21.

Lewin, S.R., Ribeiro, R.M., Walters, T., Lau, G.K., Bowden, S., Locarnini, S., and Perelson, A.S., 2001. Analysis of hepatitis B viral load decline under potent therapy: complex decay profiles observed. Hepatology 34, 1012-20.

Lipsitch, M., and Levin, B.R., 1998. Population dynamics of tuberculosis treatment: mathematical models of the roles of non-compliance and bacterial heterogeneity in the evolution of drug resistance. Int J Tuberc Lung Dis 2, 187-99.

Magombedze, G., Garira, W., and Mwenje, E., 2006. Mathematical modeling of chemotherapy of human TB infection. Journal of Biological Systems 14, 509-553.

Manca, C., Tsenova, L., Barry, C.E., 3rd, Bergtold, A., Freeman, S., Haslett, P.A., Musser, J.M., Freedman, V.H., and Kaplan, G., 1999. Mycobacterium tuberculosis CDC1551 induces a more vigorous host response in vivo and in vitro, but is not more virulent than other clinical isolates. J Immunol 162, 6740-6.

Marino, S., and Kirschner, D.E., 2004. The human immune response to Mycobacterium tuberculosis in lung and lymph node. J Theor Biol 227, 463-86.

Marino, S., Myers, A., Flynn, J.L., and Kirschner, D.E., 2010. TNF and IL-10 are major factors in modulation of the phagocytic cell environment in lung and lymph node in tuberculosis: a next-generation two-compartmental model. J Theor Biol 265, 586-98.

Mitchison, D.A., 1979. Basic mechanisms of chemotherapy. Chest 76, 771-81.

Mitchison, D.A., 1996. Modern methods for assessing the drugs used in the chemotherapy of mycobacterial disease. Soc Appl Bacteriol Symp Ser 25, 72S-80S.

Mitchison, D.A., 2005. The diagnosis and therapy of tuberculosis during the past 100 years. Am J Respir Crit Care Med 171, 699-706.

Mitchison, D.A., Jindani, A., Davies, G.R., and Sirgel, F., 2007. Isoniazid activity is terminated by bacterial persistence. J Infect Dis 195, 1871-2; author reply 1872-3. 
Neumann, A.U., Lam, N.P., Dahari, H., Gretch, D.R., Wiley, T.E., Layden, T.J., and Perelson, A.S., 1998. Hepatitis $\mathrm{C}$ viral dynamics in vivo and the antiviral efficacy of interferonalpha therapy. Science 282, 103-7.

North, R.J., and Izzo, A.A., 1993. Mycobacterial virulence. Virulent strains of Mycobacteria tuberculosis have faster in vivo doubling times and are better equipped to resist growth-inhibiting functions of macrophages in the presence and absence of specific immunity. J Exp Med 177, 1723-33.

Nuermberger, E., and Grosset, J., 2004. Pharmacokinetic and pharmacodynamic issues in the treatment of mycobacterial infections. Eur J Clin Microbiol Infect Dis 23, 243-55.

Pargal, A., and Rani, S., 2001. Non-linear pharmacokinetics of rifampicin in healthy Asian Indian volunteers. Int J Tuberc Lung Dis 5, 70-9.

Paul, S., Laochumroonvorapong, P., and Kaplan, G., 1996. Comparable growth of virulent and avirulent Mycobacterium tuberculosis in human macrophages in vitro. J Infect Dis $174,105-12$.

Peloquin, C., 2003. What is the 'right' dose of rifampin? Int J Tuberc Lung Dis 7, 3-5.

Peloquin, C.A., Jaresko, G.S., Yong, C.L., Keung, A.C., Bulpitt, A.E., and Jelliffe, R.W., 1997. Population pharmacokinetic modeling of isoniazid, rifampin, and pyrazinamide. Antimicrob Agents Chemother 41, 2670-9.

Ruslami, R., Nijland, H.M., Alisjahbana, B., Parwati, I., van Crevel, R., and Aarnoutse, R.E., 2007. Pharmacokinetics and tolerability of a higher rifampin dose versus the standard dose in pulmonary tuberculosis patients. Antimicrob Agents Chemother 51, 2546-51.

Salomon, J.A., Lloyd-Smith, J.O., Getz, W.M., Resch, S., Sanchez, M.S., Porco, T.C., and Borgdorff, M.W., 2006. Prospects for advancing tuberculosis control efforts through novel therapies. PLoS Med 3, e273.

Segovia-Juarez, J.L., Ganguli, S., and Kirschner, D., 2004. Identifying control mechanisms of granuloma formation during $\mathrm{M}$. tuberculosis infection using an agent-based model. J Theor Biol 231, 357-76.

Silver, R.F., Li, Q., and Ellner, J.J., 1998. Expression of virulence of Mycobacterium tuberculosis within human monocytes: virulence correlates with intracellular growth and induction of tumor necrosis factor alpha but not with evasion of lymphocytedependent monocyte effector functions. Infect Immun 66, 1190-9.

Sirgel, F.A., Botha, F.J., Parkin, D.P., Van De Wal, B.W., Donald, P.R., Clark, P.K., and Mitchison, D.A., 1993. The early bactericidal activity of rifabutin in patients with pulmonary tuberculosis measured by sputum viable counts: a new method of drug assessment. J Antimicrob Chemother 32, 867-75.

Sirgel, F.A., Fourie, P.B., Donald, P.R., Padayatchi, N., Rustomjee, R., Levin, J., Roscigno, G., Norman, J., McIlleron, H., and Mitchison, D.A., 2005. The early bactericidal activities of rifampin and rifapentine in pulmonary tuberculosis. Am J Respir Crit Care Med 172, 128-35.

Sirgel, F.A., Donald, P.R., Odhiambo, J., Githui, W., Umapathy, K.C., Paramasivan, C.N., Tam, C.M., Kam, K.M., Lam, C.W., Sole, K.M., and Mitchison, D.A., 2000. A multicentre study of the early bactericidal activity of anti-tuberculosis drugs. $\mathrm{J}$ Antimicrob Chemother 45, 859-70.

Tauber, S.C., and Nau, R., 2008. Immunomodulatory properties of antibiotics. Curr Mol Pharmacol 1, 68-79.

Tsiang, M., Rooney, J.F., Toole, J.J., and Gibbs, C.S., 1999. Biphasic clearance kinetics of hepatitis B virus from patients during adefovir dipivoxil therapy. Hepatology 29, 1863-9.

Wallis, R.S., Palaci, M., and Eisenach, K., 2007. Persistence, not resistance, is the cause of loss of isoniazid effect. J Infect Dis 195, 1870-1; author reply 1872-3. 
Wigginton, J.E., and Kirschner, D., 2001. A model to predict cell-mediated immune regulatory mechanisms during human infection with Mycobacterium tuberculosis. J Immunol 166, 1951-67.

World Health Organization, Global Tuberculosis Control: epidemiology, strategy, financing, World Health Organization, Geneva 2009.

Young, D., Stark, J., and Kirschner, D., 2008. Systems biology of persistent infection: tuberculosis as a case study. Nat Rev Microbiol 6, 520-8. 


\section{Tables}

Table 1. Initial conditions used for simulations with the full model

\begin{tabular}{ccc}
\hline \multicolumn{1}{c}{ Variable $^{\mathrm{a}}$} & Initial condition & Unit \\
\hline $\begin{array}{c}\left(\mathrm{M}_{\mathrm{R}}\right) \\
\text { Resident macrophages in lungs }\end{array}$ & $5 * 10^{5}$ & Cells $/ \mathrm{ml}$ \\
Naive T-cells in lymph node (T) & $4 * 10^{3}$ & Cells $/ \mathrm{m}^{3}$ of tissue \\
Immature dendritic cells in \\
$\begin{array}{c}\text { lymph node (IDC) } \\
\text { Extracellular bacteria in lungs } \\
\left(\mathrm{B}_{\mathrm{E}}\right)\end{array}$ & 500 (latency) & Cells $/ \mathrm{m}^{3}$ of tissue \\
${ }^{\mathrm{a}}$ Initial conditions for the other variables were set at zero & Bacteria $/ \mathrm{ml}$ \\
\hline
\end{tabular}


Table 2. Parameter values of the pharmacodynamic model used for simulations of rifampin therapy

\begin{tabular}{|c|c|c|c|c|}
\hline Parameter & Value & Unit & Definition & Reference \\
\hline $\mathrm{K}_{\mathrm{gmax}(\mathrm{E})}$ & 0,03 & $\mathrm{~h}^{-1}$ & Maximal growth rate of $B_{E}$ & $\begin{array}{l}\text { (Manca et al., 1999; } \\
\text { North and Izzo, 1993) }\end{array}$ \\
\hline $\mathrm{B}_{\text {Emax }}$ & $10^{9}$ & $\mathrm{~B}_{\mathrm{E}} / \mathrm{ml}$ & Maximal number of $B_{E}$ & $\begin{array}{l}\text { (Allen and Mitchison, } \\
\text { 1992) }\end{array}$ \\
\hline $\mathrm{K}_{\operatorname{gmax}(I)}$ & 0,015 & $\mathrm{~h}^{-1}$ & Maximal growth rate of $B_{I}$ & $\begin{array}{c}\text { (Chanwong et al., 2007; } \\
\text { Jayaram et al., 2003; Paul } \\
\text { et al., 1996; Silver et al., } \\
\text { 1998) }\end{array}$ \\
\hline $\mathrm{m}$ & 2 & None & Hill coefficient & $\begin{array}{l}\text { (Marino and Kirschner, } \\
\text { 2004) }\end{array}$ \\
\hline $\mathrm{N}$ & 50 & $\mathrm{~B}_{\mathrm{I}} / \mathrm{M}_{\mathrm{I}}$ & Maximal bacterial load of $\mathrm{M}_{\mathrm{I}}$ & $\begin{array}{l}\text { (Marino and Kirschner, } \\
\text { 2004) }\end{array}$ \\
\hline $\mathrm{EC}_{50 \mathrm{~g}}$ & 1,932 & $\mathrm{mg} / \mathrm{L}$ & $\begin{array}{l}\text { Median effective concentration for } \\
\text { RIF effect on bacterial growth }\end{array}$ & (Gumbo et al., 2007c) \\
\hline$\alpha_{\mathrm{g}}$ & 0,361 & None & $\begin{array}{l}\text { Hill coefficient for RIF effect on } \\
\text { bacterial growth }\end{array}$ & (Gumbo et al., 2007c) \\
\hline $\mathrm{k}_{\mathrm{kmax}(\mathrm{E})}$ & 0,576 & $\mathrm{~h}^{-1}$ & Maximal kill rate of RIF on $B_{E}$ & (Jayaram et al., 2003) \\
\hline $\mathrm{EC}_{50 \mathrm{k}}$ & 7,652 & $\mathrm{mg} / \mathrm{L}$ & $\begin{array}{l}\text { Median effective concentration for } \\
\text { RIF killing }\end{array}$ & (Gumbo et al., 2007c) \\
\hline$\alpha_{k}$ & 1,388 & None & Hill coefficient for RIF killing effect & (Gumbo et al., 2007c) \\
\hline $\mathrm{k}_{\mathrm{kmax}(\mathrm{I})}$ & 0,0504 & $\mathrm{~h}^{-1}$ & Maximal kill rate of RIF on $B_{I}$ & (Jayaram et al., 2003) \\
\hline
\end{tabular}




\section{ACCEPTED MANUSCRIPT}

Table 3. Pharmacokinetic parameter values used for simulations of rifampin therapy

\begin{tabular}{lcllllllll}
\hline & $\mathrm{K}_{\mathrm{A}}\left(\mathrm{h}^{-1}\right)$ & $\mathrm{K}_{\mathrm{E}}\left(\mathrm{h}^{-1}\right)$ & $\mathrm{K}_{12}\left(\mathrm{~h}^{-1}\right)$ & $\mathrm{K}_{21}\left(\mathrm{~h}^{-1}\right)$ & $\mathrm{K}_{23}\left(\mathrm{~h}^{-1}\right)$ & $\mathrm{K}_{32}\left(\mathrm{~h}^{-1}\right)$ & $\mathrm{V}_{1}(\mathrm{~L})$ & $\mathrm{V}_{2}(\mathrm{~L})$ & $\mathrm{V}_{3}(\mathrm{~L})$ \\
\hline Median & 2.00 & 1.18 & 39.43 & 19.29 & 46.01 & 22.18 & 5.31 & 78.0 & 27.09 \\
Min & 0.25 & 0.025 & 1.57 & 2.53 & 0.034 & 1.28 & 1.55 & 24.20 & 8.61 \\
$\operatorname{Max}$ & 10.0 & 5.0 & 49.9 & 50.0 & 50.0 & 50.0 & 46.4 & 200 & 200 \\
\hline
\end{tabular}


Table 4. Comparison of extracellular bactericidal activities of three rifampin dosage regimens predicted by the full model with published data of early bactericidal activity

\begin{tabular}{|c|c|c|c|c|c|}
\hline \multirow{2}{*}{$\begin{array}{l}\text { Rifampin } \\
\text { daily dose }\end{array}$} & \multirow{2}{*}{$\begin{array}{l}\text { Period } \\
\text { (days) }\end{array}$} & \multicolumn{2}{|c|}{$\begin{array}{l}\text { Bactericidal activity } \\
\text { predicted }\left(\log _{10}\right. \\
\left.\mathrm{B}_{\mathrm{E}} / \mathrm{ml} / \text { day }\right)^{\mathrm{a}}\end{array}$} & \multicolumn{2}{|c|}{$\begin{array}{l}\text { Published values of EBA } \\
\qquad\left(\log _{10} \mathrm{CFU} / \mathrm{ml} / \text { day }\right)\end{array}$} \\
\hline & & $\begin{array}{l}\text { Mean } \\
(\mathrm{SD})\end{array}$ & Median & Mean (SD) & Reference \\
\hline \multirow{4}{*}{$\begin{array}{l}300 \mathrm{mg} \text { or } \\
5 \mathrm{mg} / \mathrm{kg}\end{array}$} & $0-2$ & $\begin{array}{l}0.102 \\
(0.090)\end{array}$ & 0.107 & $\begin{array}{c}0.062(0.175) \\
0.150 \\
0.121(0.130)\end{array}$ & $\begin{array}{c}\text { (Jindani et al., 2003; Jindani et al., 1980) } \\
\text { (Sirgel et al., 1993) } \\
\text { (Sirgel et al., 2005) }\end{array}$ \\
\hline & $0-5$ & $\begin{array}{c}0.117 \\
(0.156)\end{array}$ & 0.088 & $0.111(0.072)$ & (Sirgel et al., 2005) \\
\hline & $2-5$ & $\begin{array}{c}0.127 \\
(0.209)\end{array}$ & 0.069 & $0.104(0.061)$ & (Sirgel et al., 2005) \\
\hline & $2-14$ & $\begin{array}{c}0.093 \\
(0.132)\end{array}$ & 0.042 & $0.072(0.052)$ & (Jindani et al., 2003; Jindani et al., 1980) \\
\hline \multirow{4}{*}{$\begin{array}{l}600 \mathrm{mg} \text { or } \\
10 \mathrm{mg} / \mathrm{kg}\end{array}$} & $0-2$ & $\begin{array}{c}0.277 \\
(0.229)\end{array}$ & 0.294 & $\begin{array}{c}0.174(0.228) \\
0.20(0.04) \\
0.63(0.48)^{b} ; 0.17(0.16) \\
0.221(0.247) \\
0.29(0.30) \\
0.28(0.21)\end{array}$ & $\begin{array}{r}\text { (Jindani et al., 2003; Jindani et al., 1980) } \\
\text { (Sirgel et al., 1993) } \\
\text { (Sirgel et al., 2000) } \\
\text { (Sirgel et al., 2005) } \\
\text { (Chan et al., 1992) } \\
\text { (Gosling et al., 2003) }\end{array}$ \\
\hline & $0-5$ & $\begin{array}{c}0.302 \\
(0.279)\end{array}$ & 0.283 & $0.226(0.144)$ & (Sirgel et al., 2005) \\
\hline & $2-5$ & $\begin{array}{c}0.319 \\
(0.323)\end{array}$ & 0.263 & $0.202(0.109)$ & (Sirgel et al., 2005) \\
\hline & $2-14$ & $\begin{array}{c}0.194 \\
(0.156)\end{array}$ & 0.235 & $0.096(0.051)$ & (Jindani et al., 2003; Jindani et al., 1980) \\
\hline \multirow{4}{*}{$\begin{array}{l}1200 \mathrm{mg} \text { or } \\
20 \mathrm{mg} / \mathrm{kg}\end{array}$} & $0-2$ & $\begin{array}{r}0.659 \\
(0.512)\end{array}$ & 0.693 & $\begin{array}{c}0.383(0.326) \\
0.44(0.24)\end{array}$ & $\begin{array}{c}\text { (Jindani et al., 2003; Jindani et al., 1980) } \\
\text { (Diacon et al., 2007) }\end{array}$ \\
\hline & & $(0.372)$ & 0.649 & $0.30(0.11)$ & Diacon et al. (2007) \\
\hline & $2-5$ & $\begin{array}{c}0.456 \\
(0.316)\end{array}$ & 0.551 & & \\
\hline & $2-14$ & $\begin{array}{l}0.222 \\
(0.142)\end{array}$ & 0.300 & $0.154(0.086)$ & (Jindani et al., 2003; Jindani et al., 1980) \\
\hline
\end{tabular}

${ }^{a}$ Results from 34 simulated subjects; ${ }^{b}$ Data from the Cape town center ; ${ }^{c}$ Data from the Hong Kong center 


\section{Figure legends}

Figure 1. Dynamics of extracellular and intracellular bacteria during latent tuberculosis. BE, extracellular bacteria; BI, intracellular bacteria

Figure 2. Dynamics of pulmonary macrophages (A) and dendritic cells (B) during latent tuberculosis. MR, resident macrophages; MA, activated macrophages; MI, infected macrophages; IDC, immature dendritic cells; MDC, mature dendritic cells

Figure 3. Dynamics of extracellular and intracellular bacteria during active tuberculosis. BE, extracellular bacteria; BI, intracellular bacteria

Figure 4. Dynamics of pulmonary macrophages (A) and dendritic cells (B) during active tuberculosis. MR, resident macrophages; MA, activated macrophages; MI, infected macrophages; IDC, immature dendritic cells; MDC, mature dendritic cells

Figure 5. Evolution of the number of bacteria in lungs during active tuberculosis and during 2-month of treatment by rifampin (starting at day 180). Red lines, extracellular bacteria; blue lines: intracellular bacteria. A, Profiles over the full time-sequence; B, Focus on the rifampin therapy period

Figure 6. Concentration-time profiles in plasma (A) and lungs (B) simulated with 34 subject individual Bayesian posterior PK parameter values over the first three days of rifampin treatment (600 mg/day). Red line, plasma concentration; black thick line, median of the 34 plasma concentrations; blue line, concentration in the ELF; black thick line, median of the 34 
concentrations in the ELF; magenta line, concentration in alveolar cells; purple thick line, median of the 34 concentrations in alveolar cells.

Figure 7. Comparison of the effect of three rifampin dosage regimens on the bacterial dynamics. Results were calculated using the median value of the 34-subject set of PK parameters

Figure 8. Antibacterial effect of rifampin on extracellular bacteria over the first 14 days of therapy. A, $300 \mathrm{mg} /$ day; B, $600 \mathrm{mg} /$ day; C, $1200 \mathrm{mg} /$ day. For each panel, the black line is the median of the individual data

Figure 9. Dose dependency of the biphasic early antibacterial effect of rifampin. A, Bactericidal activity predicted by the model; B, EBA data from Jindani (Jindani et al., 2003; Jindani et al., 1980).

Figure 10. Dynamics of extracellular and intracellular bacteria simulated with the PK/PD model. The regimen simulated was $1200 \mathrm{mg}$ / day during 20 days. Solid line, $\mathrm{B}_{\mathrm{E}}$; dashed line, $\mathrm{B}_{\mathrm{I}}$. Each curve represents the median value of the results from the 34 virtual subjects.

Figure 11. Influence of the transfer rate constant from the extracellular to the intracellular bacterial compartment $\mathrm{K}_{\mathrm{EI}}$ on the antibacterial effect of rifampin on $\mathrm{BE}(\mathrm{A})$ and $\mathrm{BI}(\mathrm{B})$ over the first 20 days of therapy. Equation $6 \mathrm{~b}$ was used with $\mathrm{K}_{\mathrm{IE}}=0.0005 \mathrm{~h}^{-1}$. The rifampin dose simulated was $600 \mathrm{mg}$ / day. Each curve represents the median value of the 34 virtual subjects 


\section{ACCEPTED MANUSCRIPT}

Figure 12. Influence of the transfer rate constant from the intracellular to the extracellular bacterial compartment $\mathrm{K}_{\mathrm{IE}}$ on the antibacterial effect of rifampin on $\mathrm{BE}(\mathrm{A})$ and $\mathrm{BI}(\mathrm{B})$ over the first 20 days of therapy. Equation $6 \mathrm{~b}$ was used with $\mathrm{K}_{\mathrm{EI}}=0.001 \mathrm{~h}^{-1}$. The rifampin dose simulated was $600 \mathrm{mg} /$ day. Each curve represents the median value of the 34 simulated subjects

Figure 13. Model of decline of tuberculosis bacilli in sputum during antituberculosis therapy and the special populations hypothesis. Figure inspired by Mitchison (Mitchison, 1996) and drawn with data from Davies (Davies et al., 2006) 


\section{ACCEPTED MANUSCRIPT}

\section{Highlights}

$>$ We present a mathematical model of pulmonary tuberculosis therapy by rifampin. $>$ The model is based on pharmacokinetic, pharmacodynamic and disease submodels. $>$ The model simulates the bacterial dynamics of TB from the first day of infection to the last day of therapy. $>$ The model reproduces some properties of the bactericidal activity of rifampin observed in clinical studies. $>$ The model suggests a new hypothesis for bacterial persistence during TB treatment. 


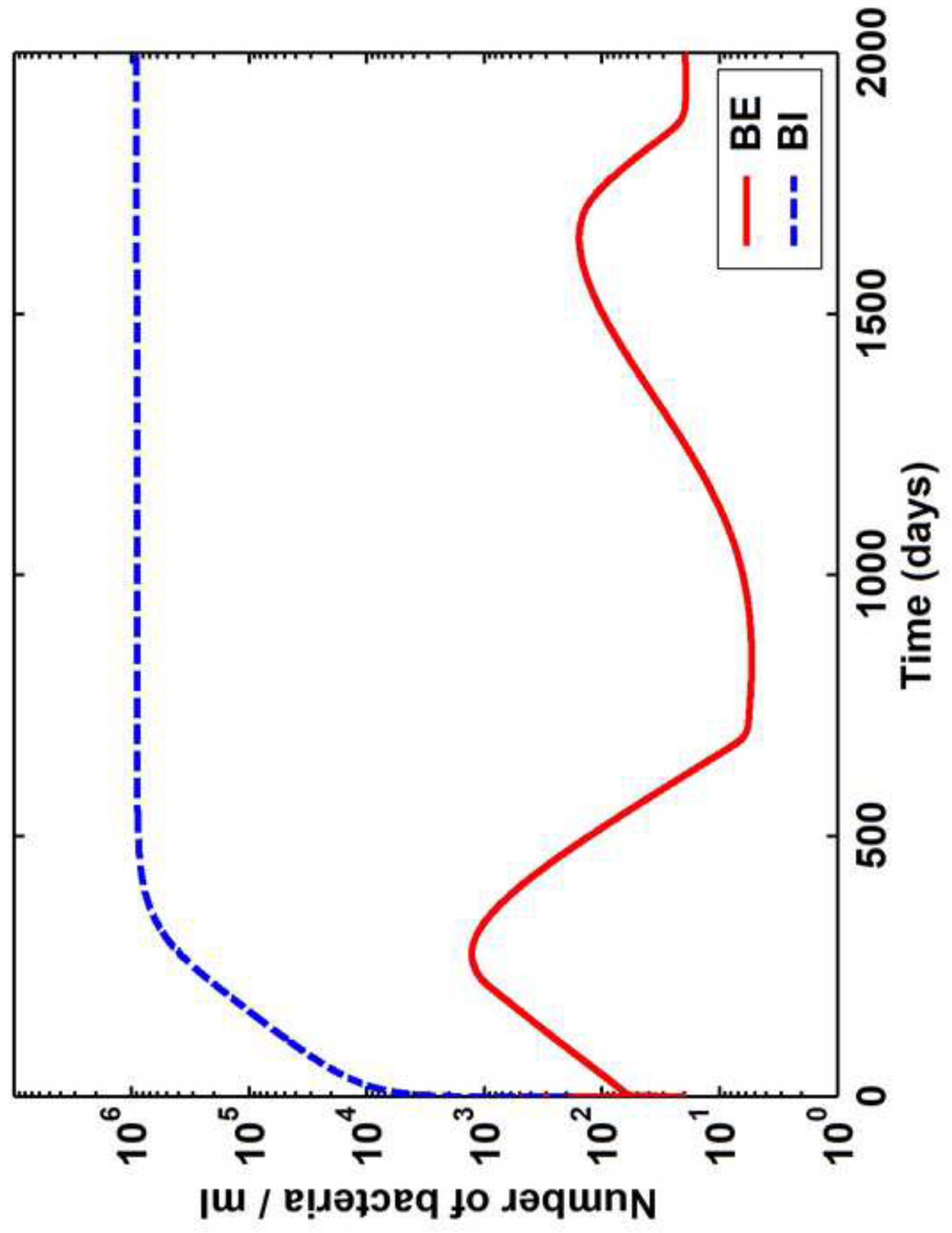




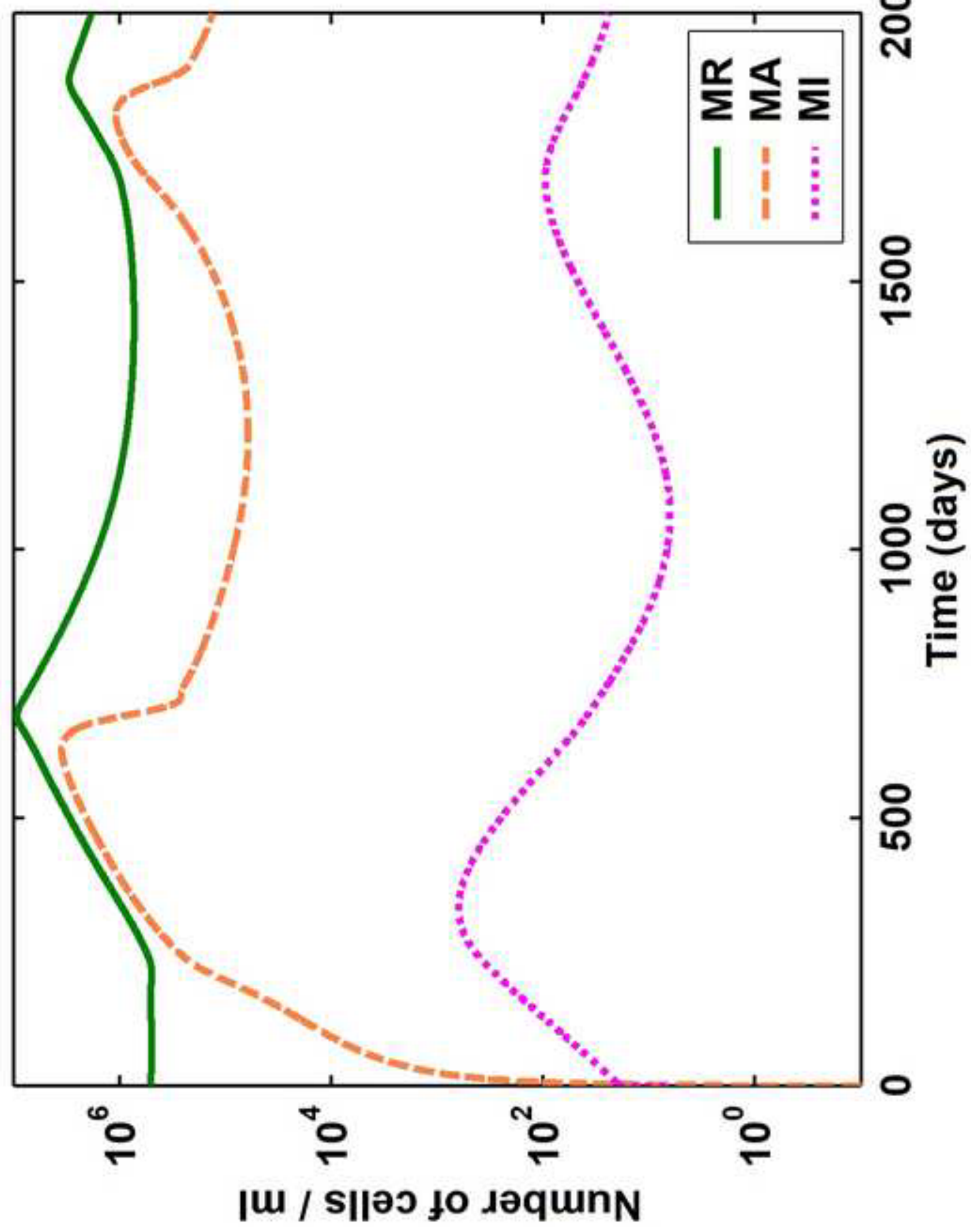




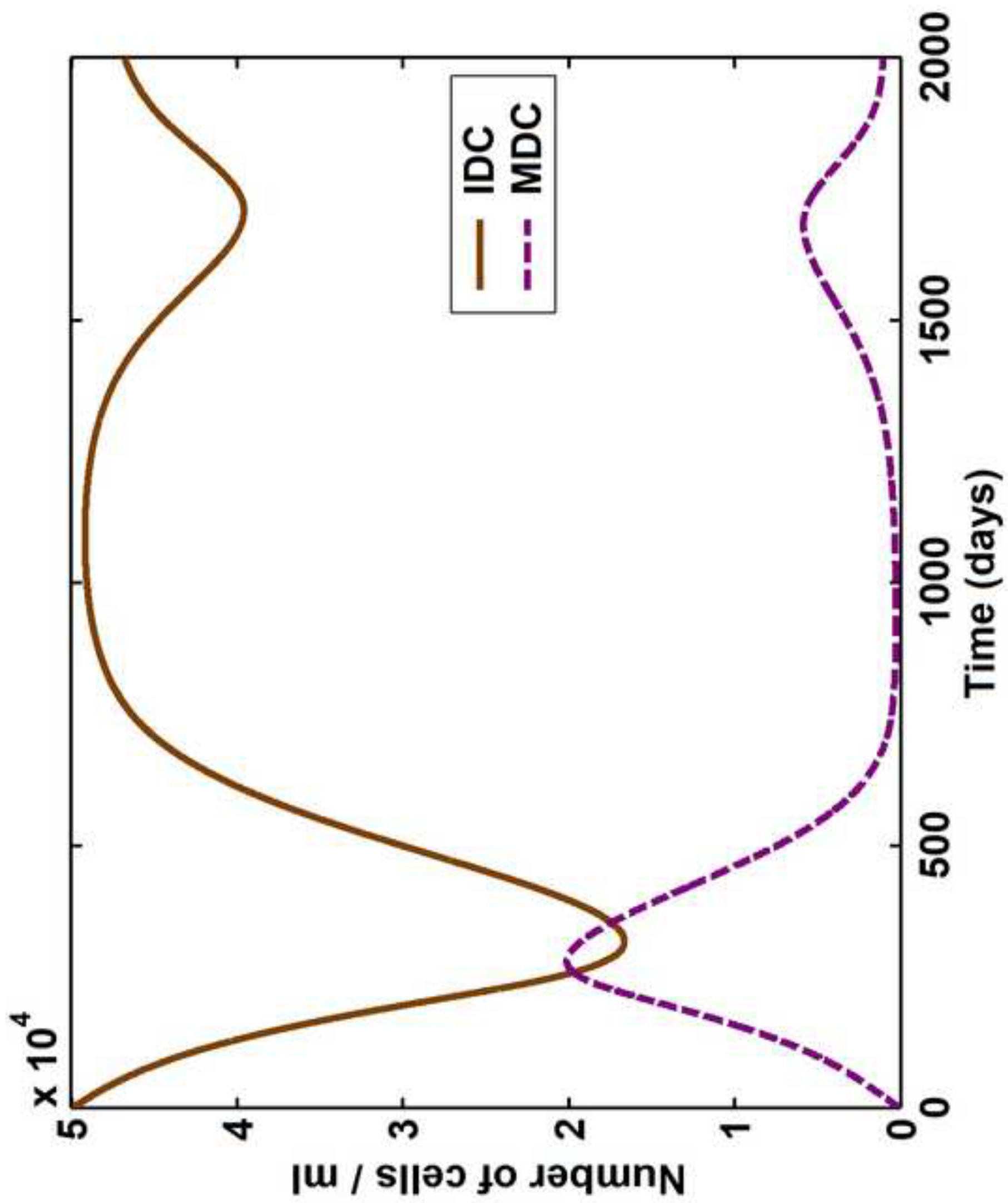




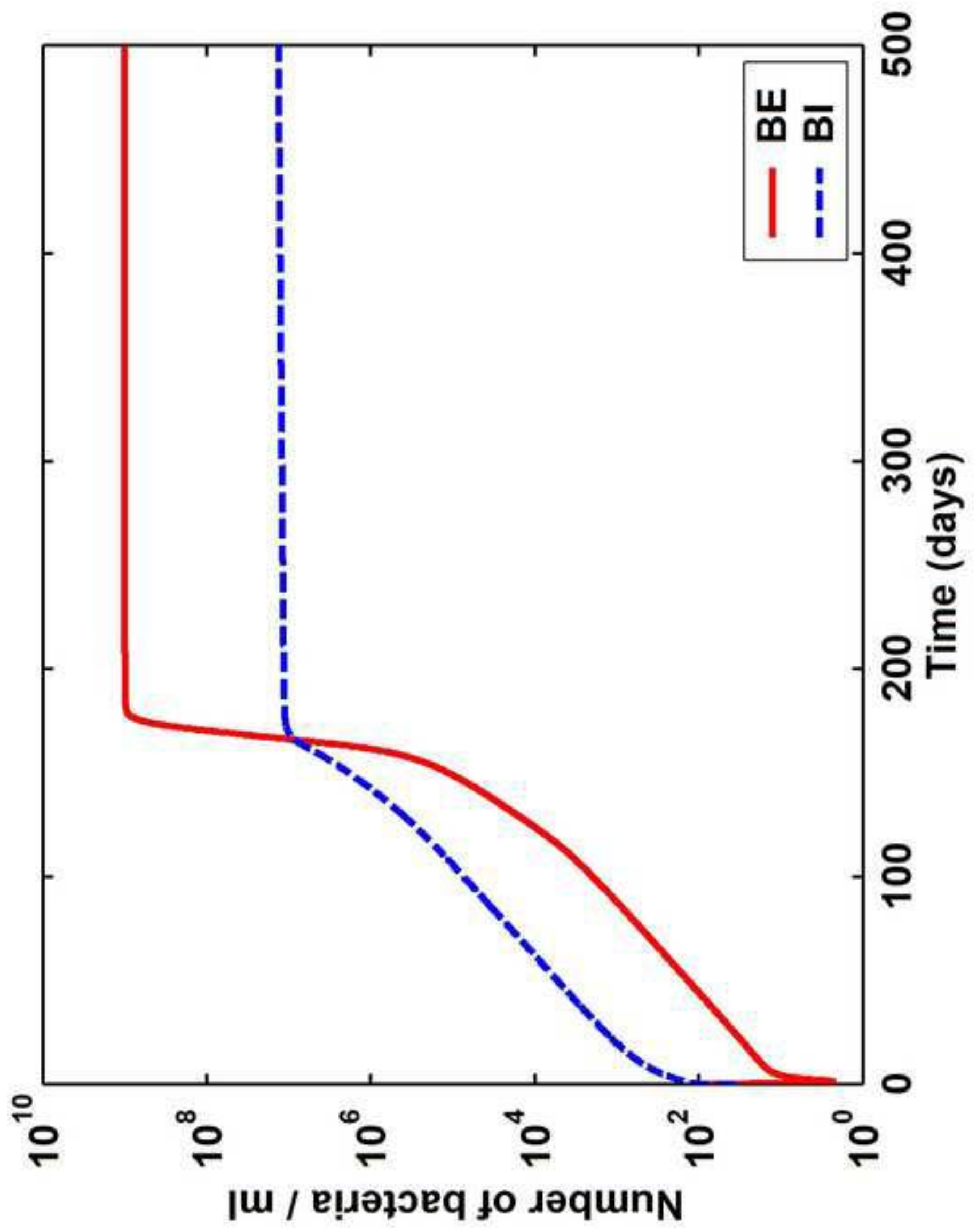




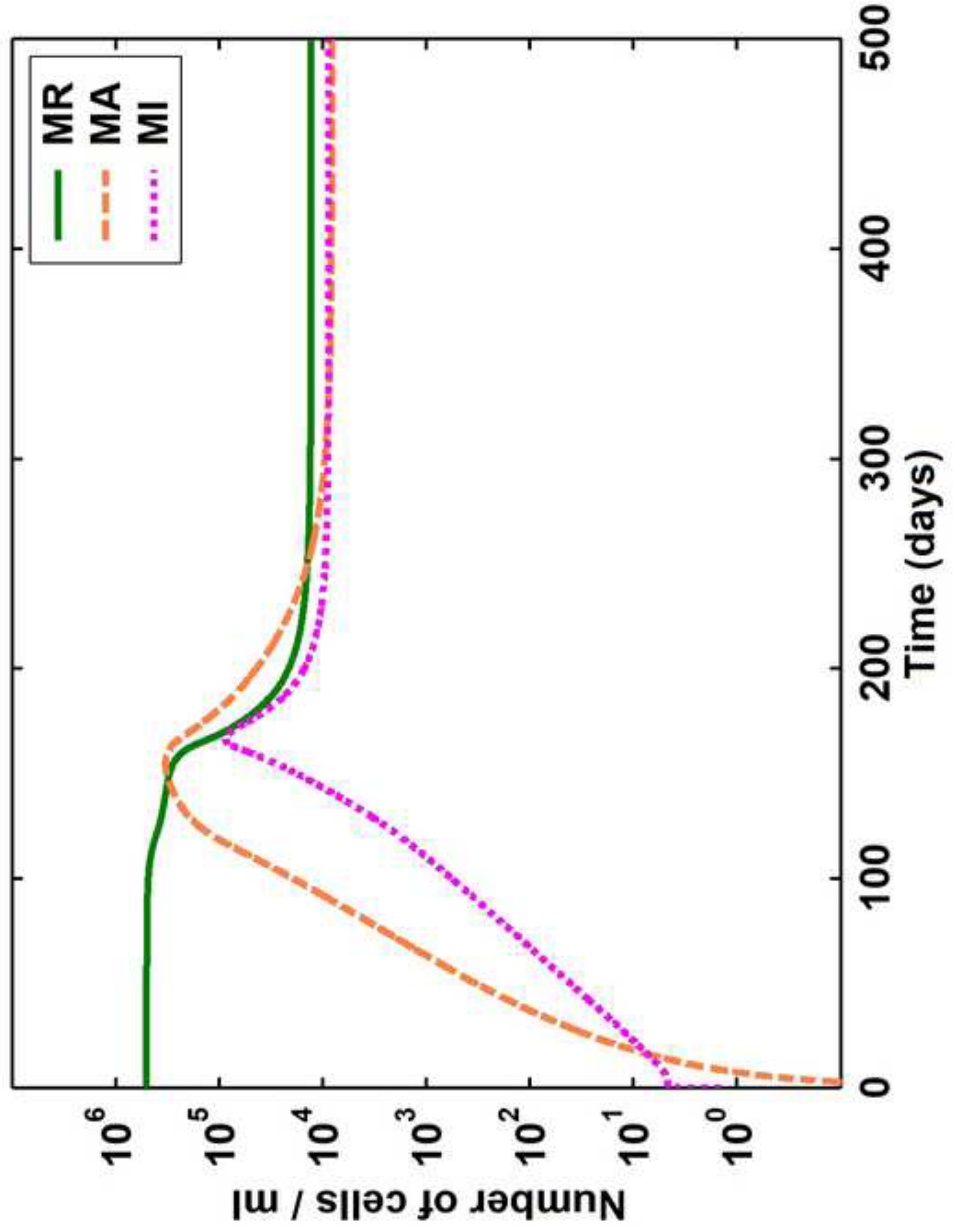




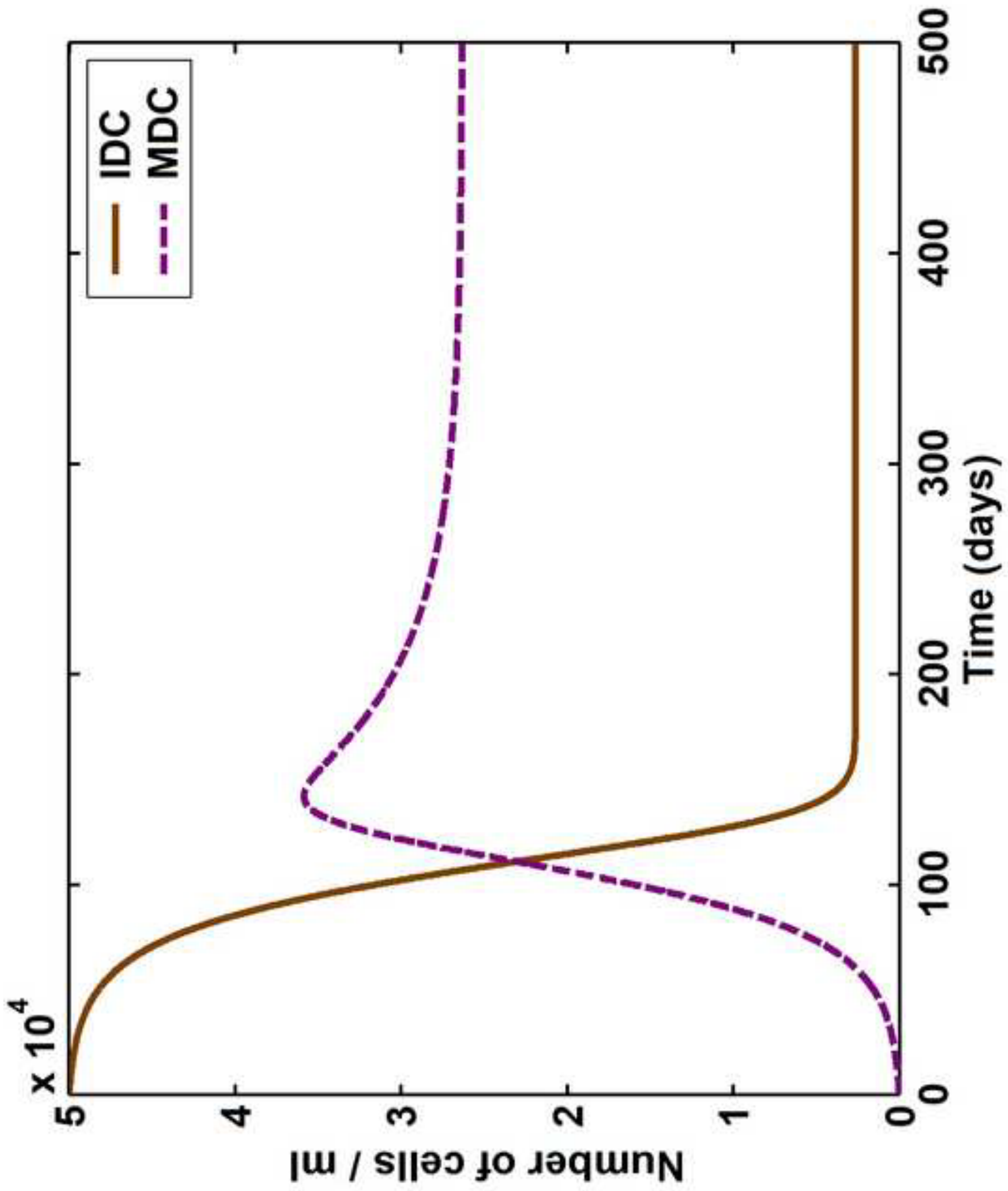




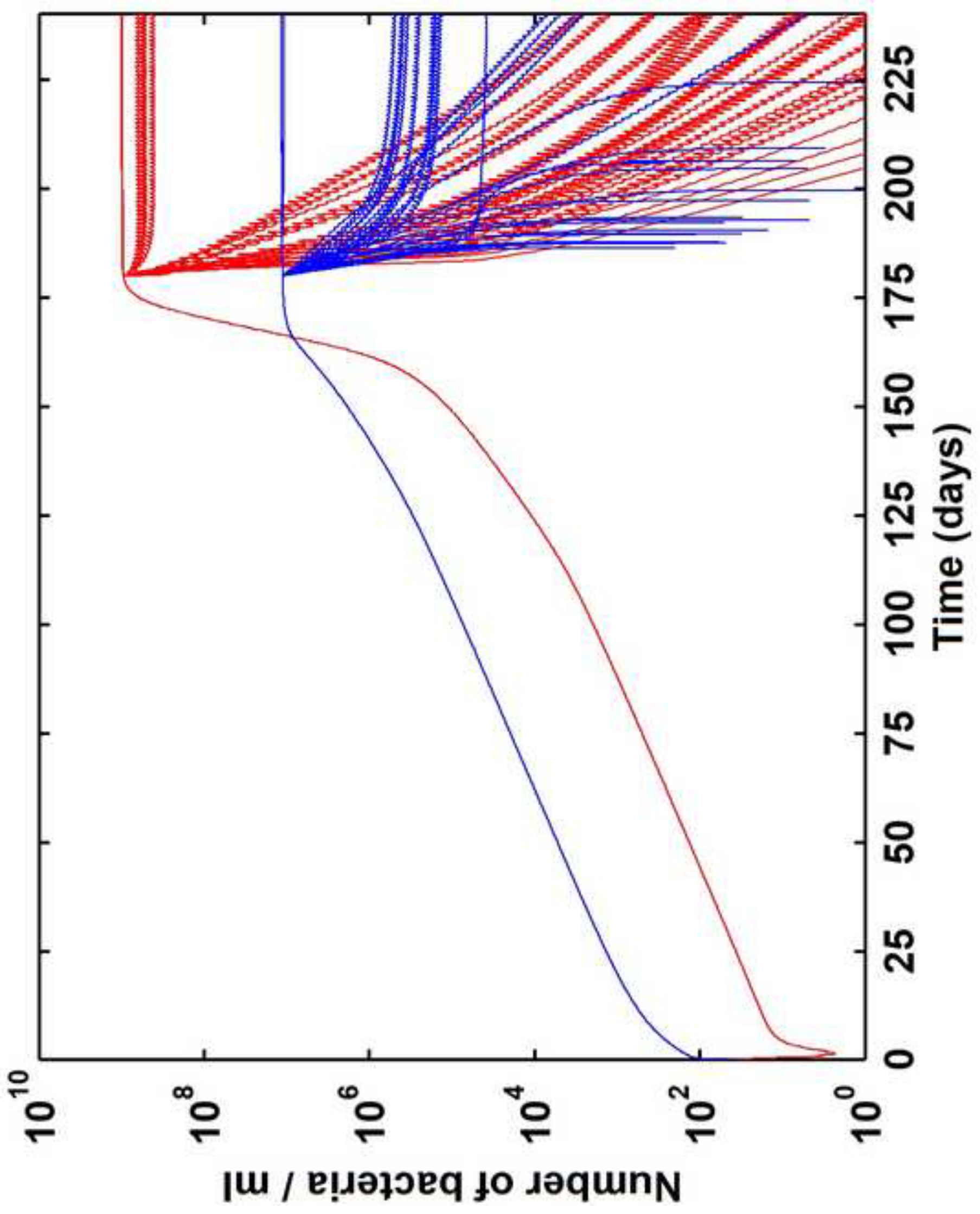




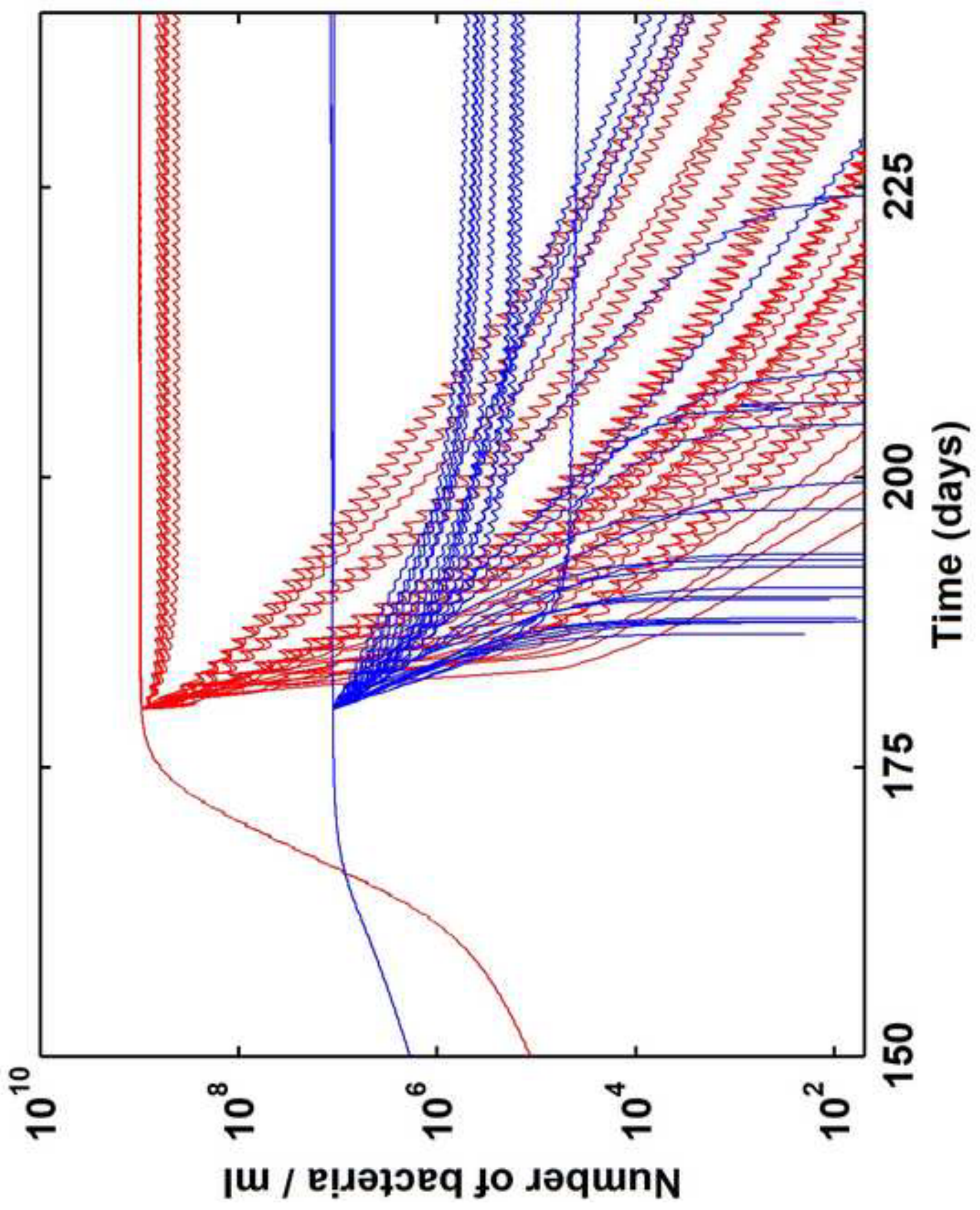




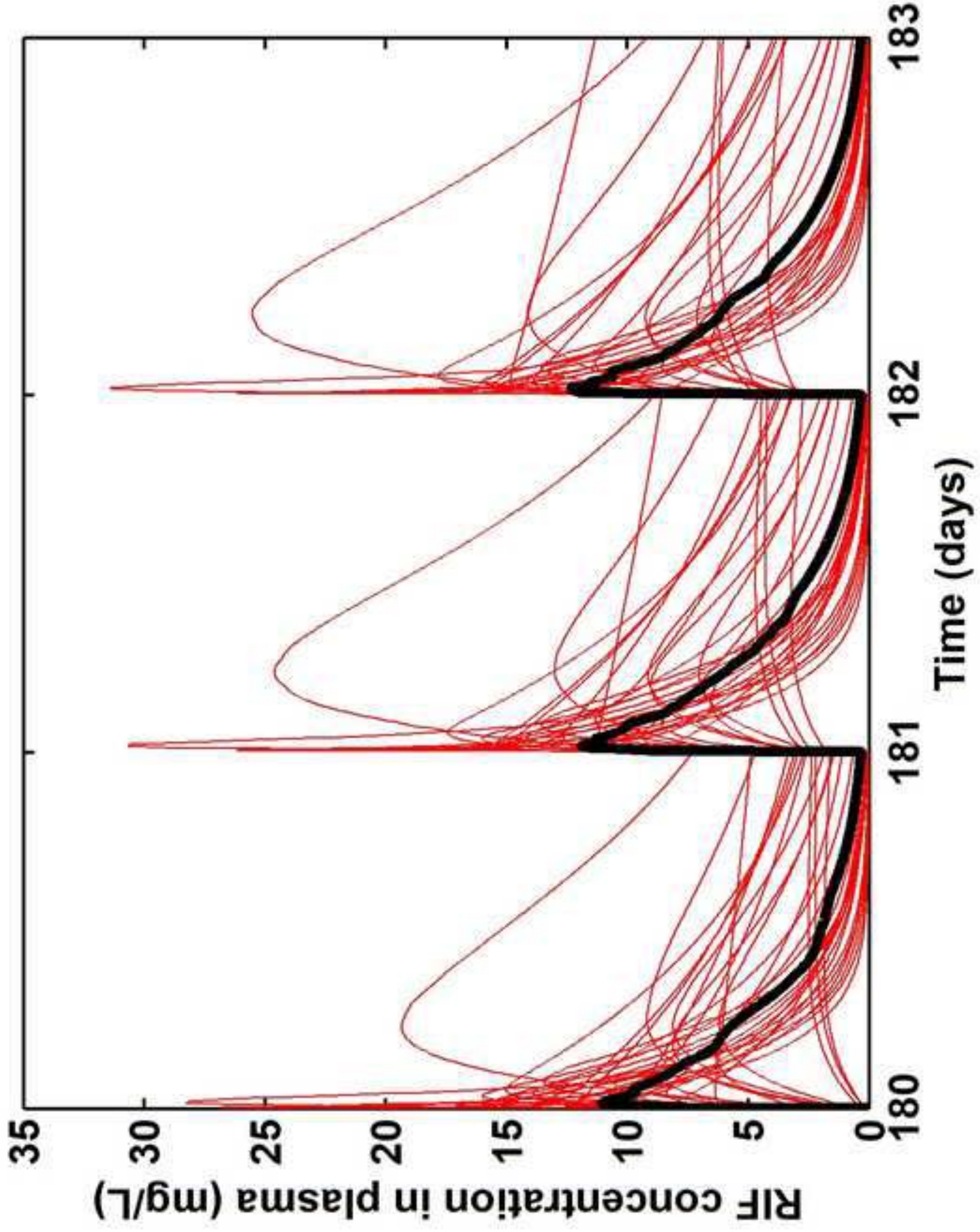

$\frac{\text { 은 }}{\text { 음 }}$ 


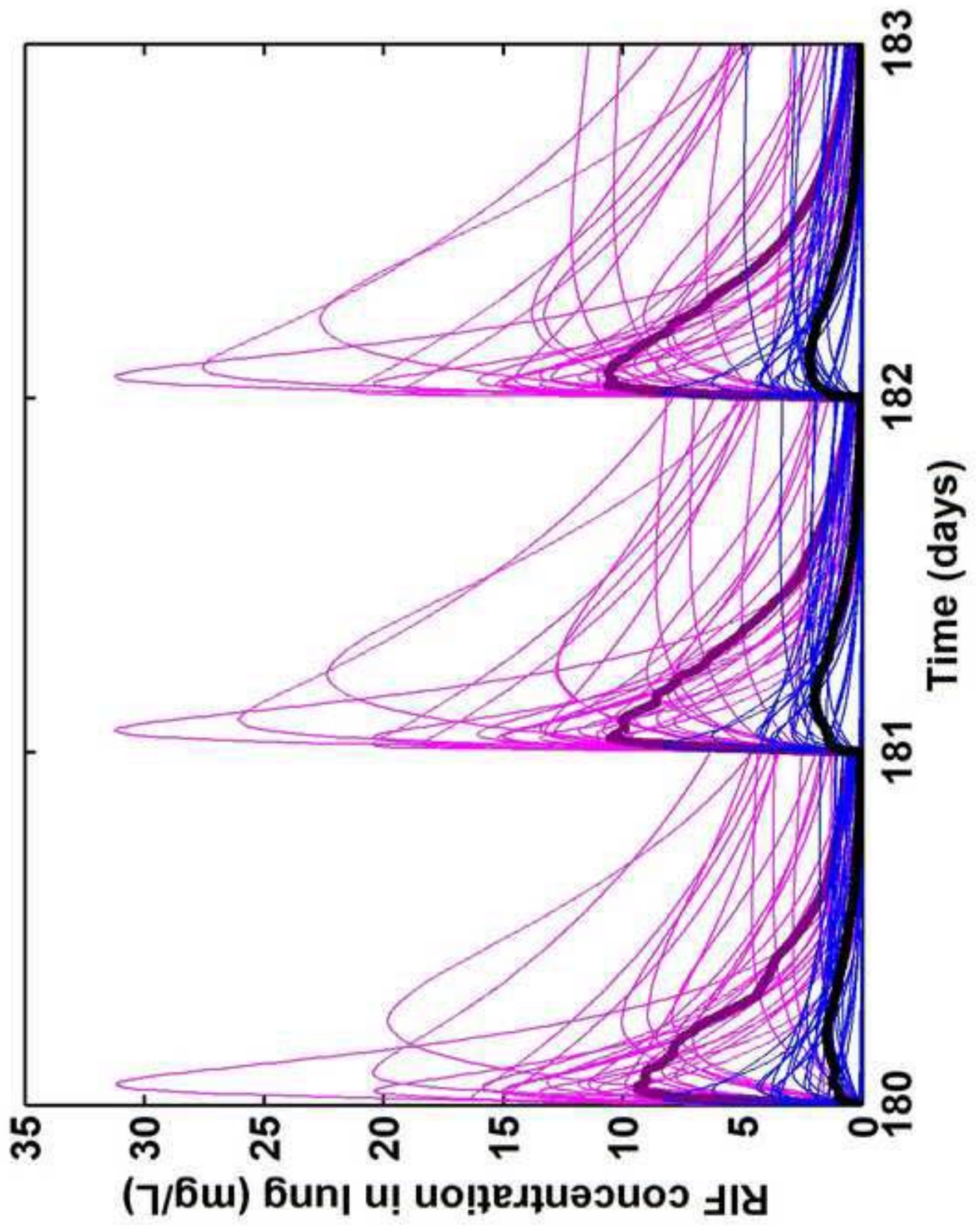

문 


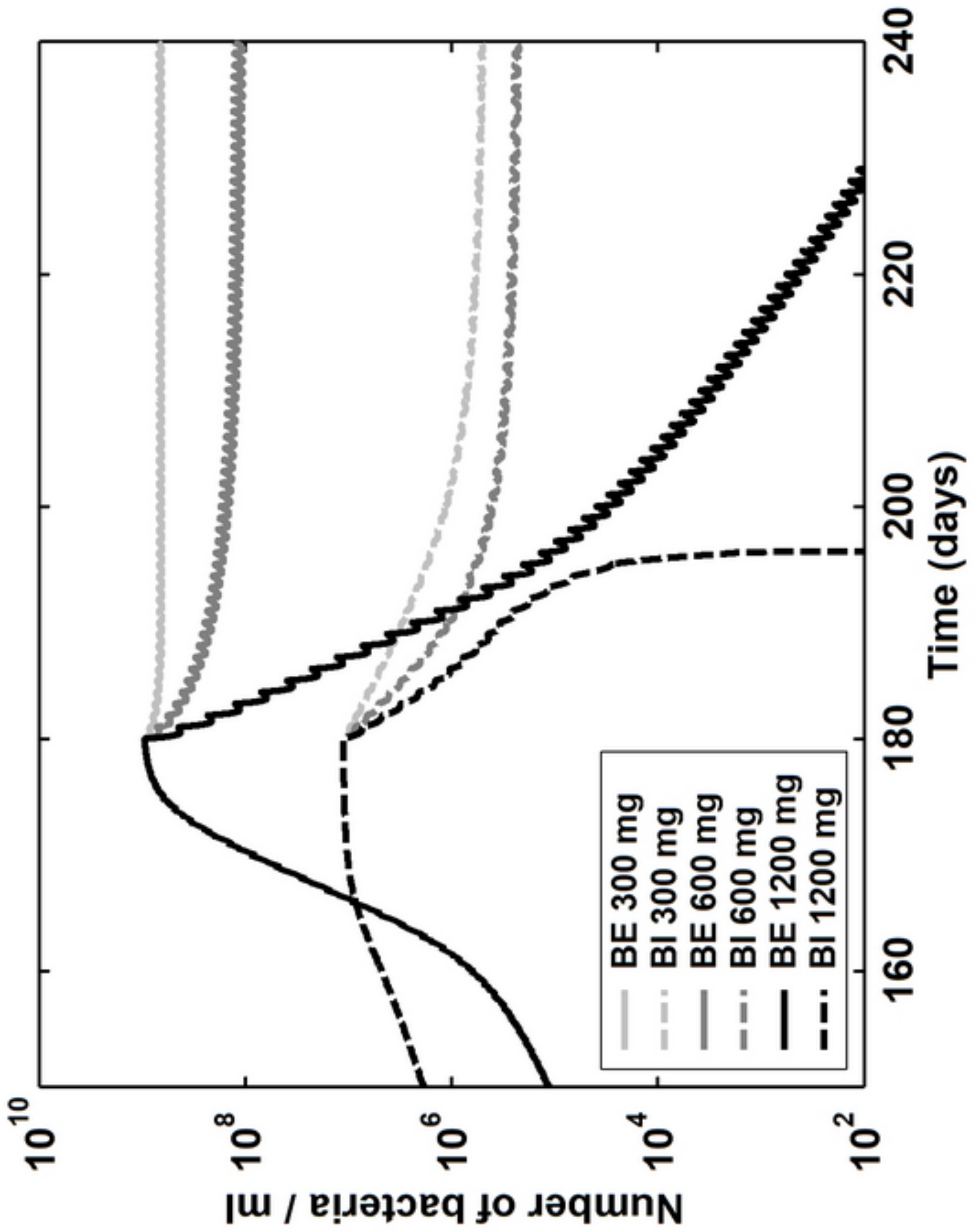




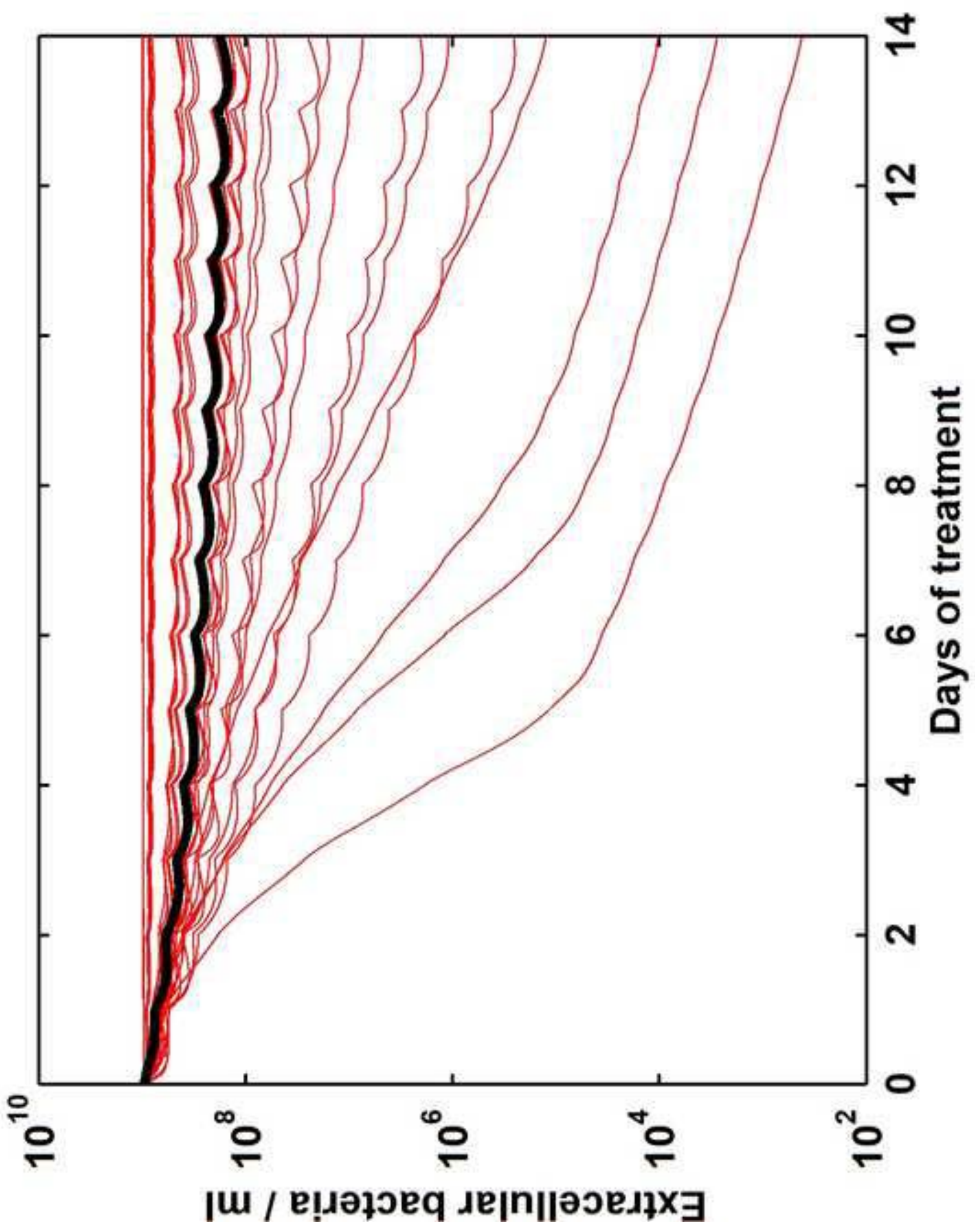




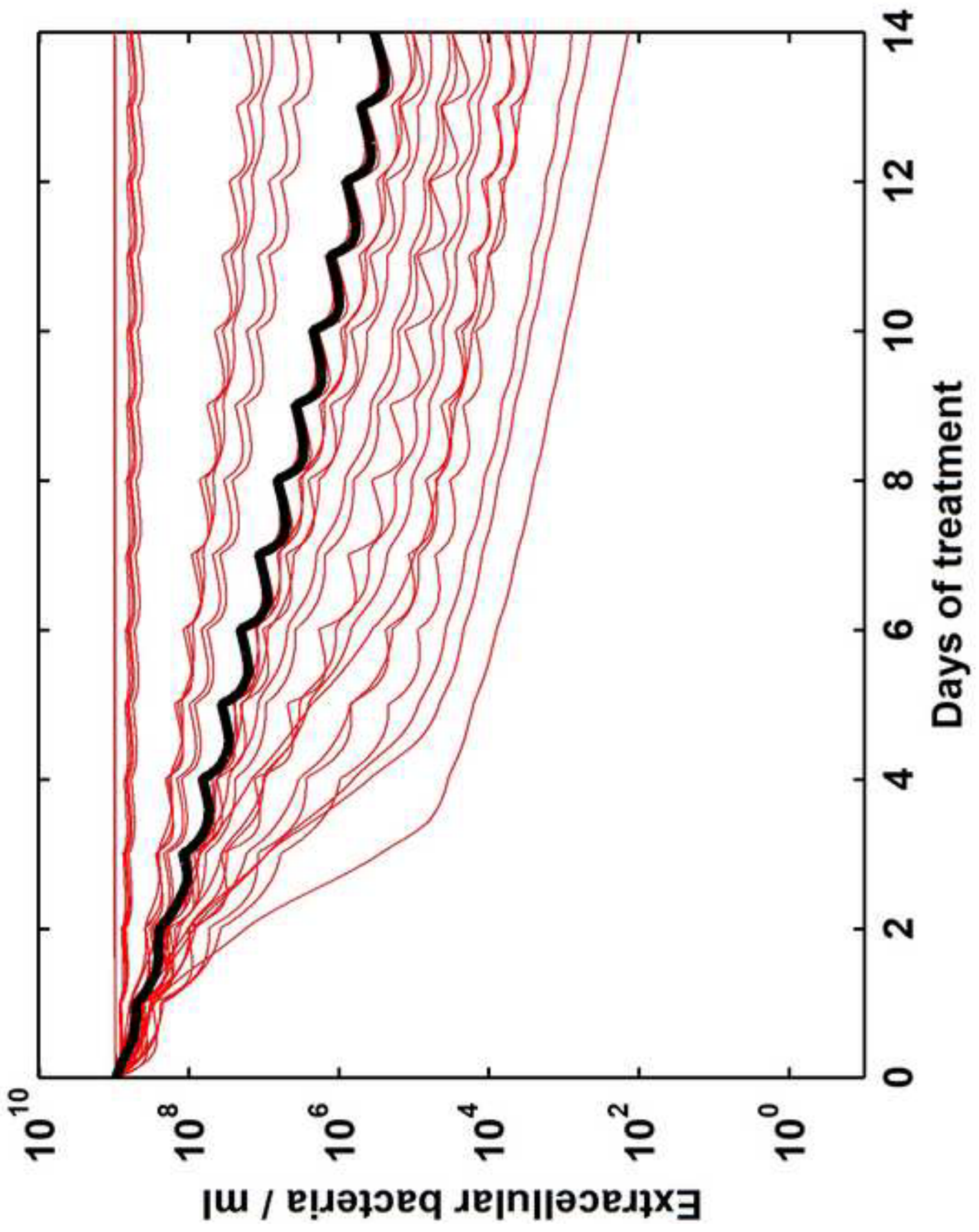




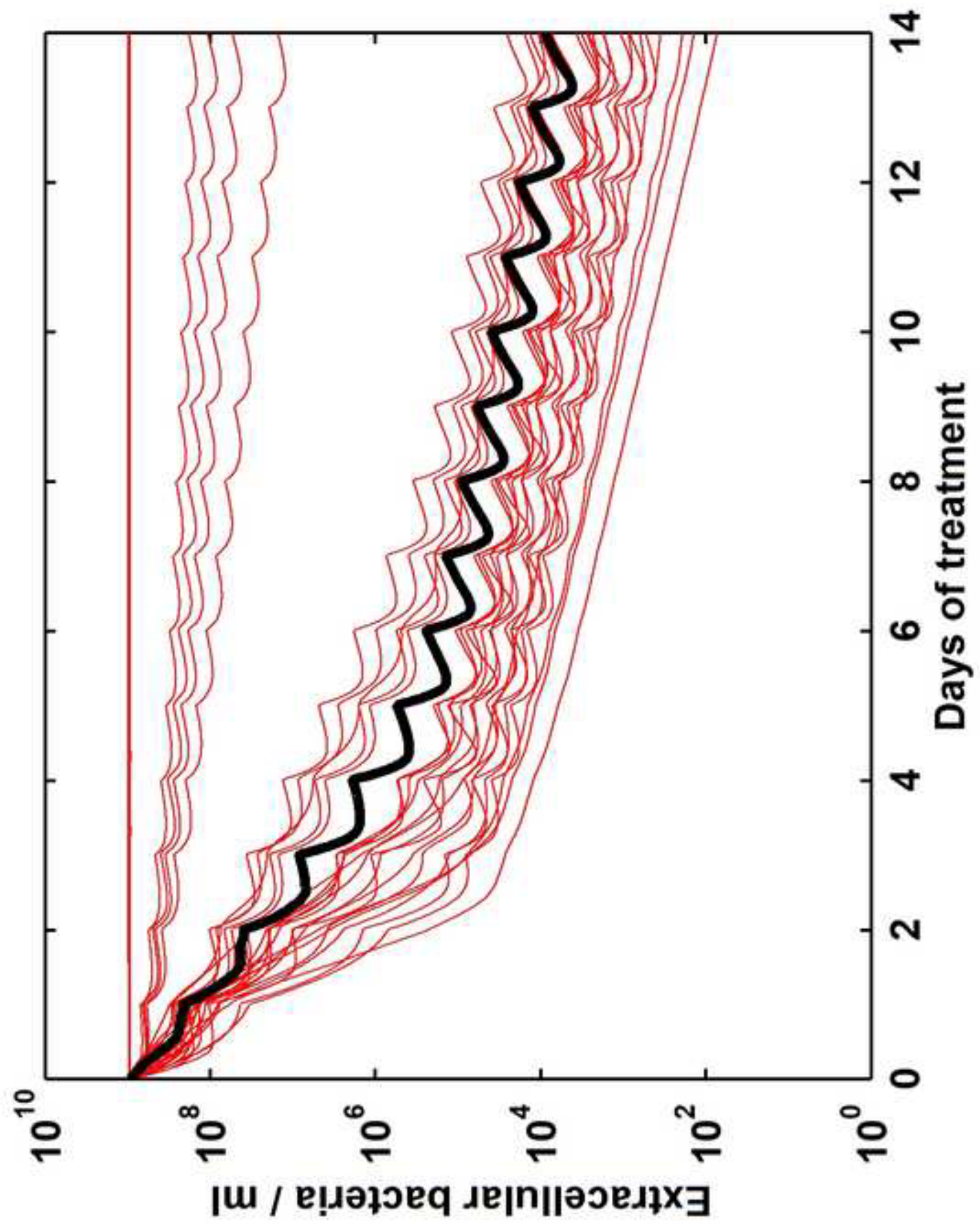



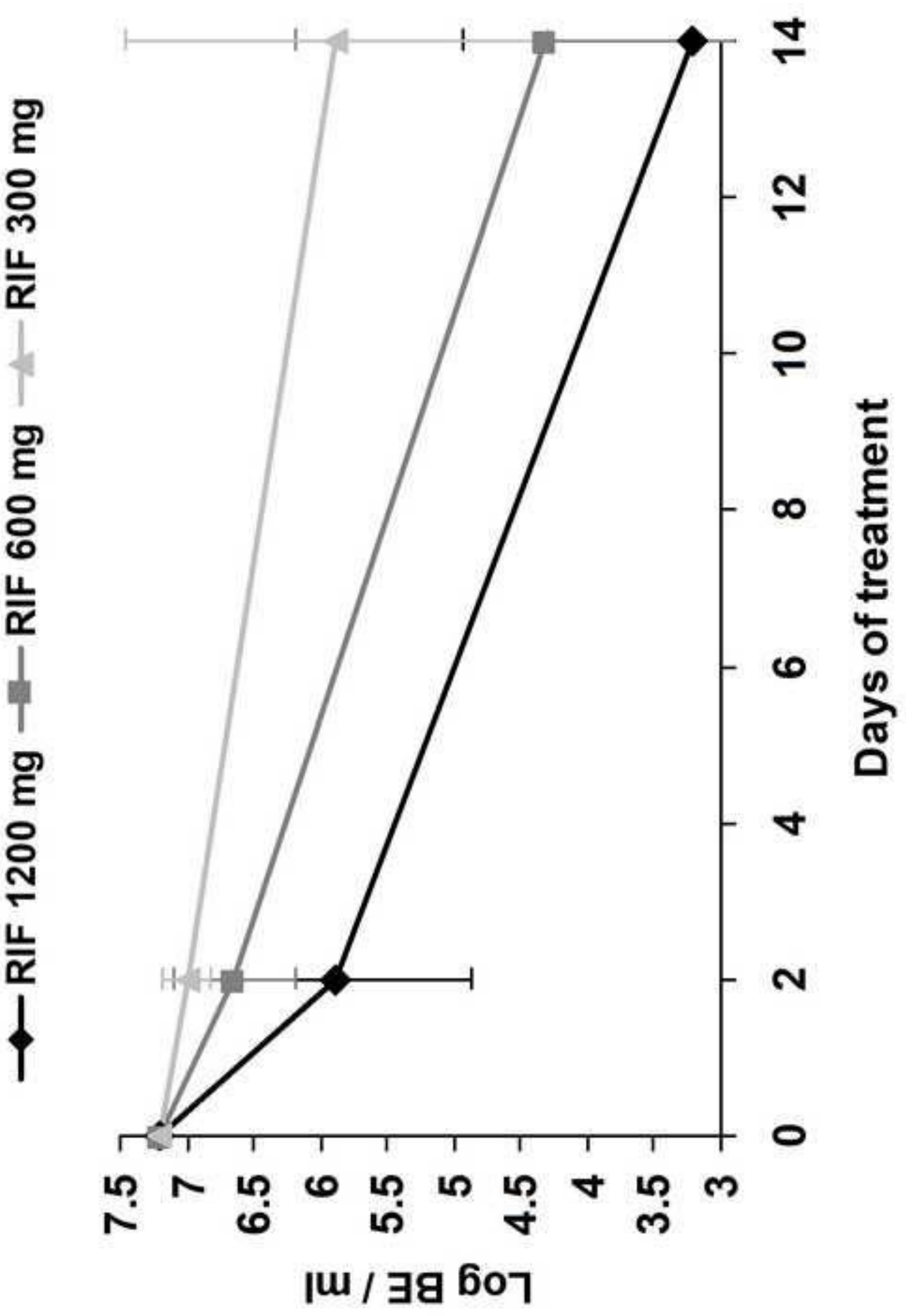

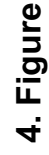




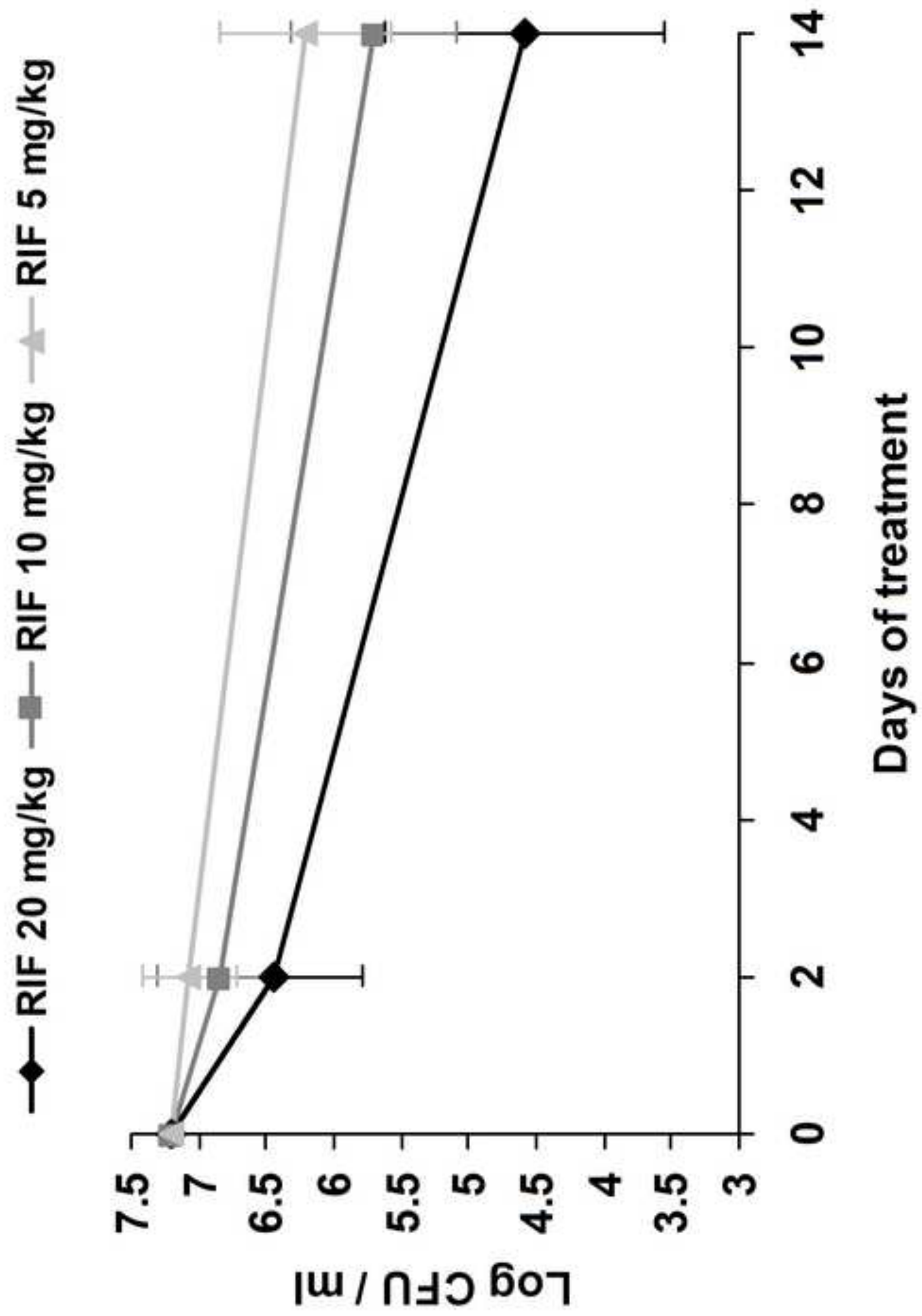

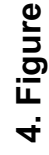




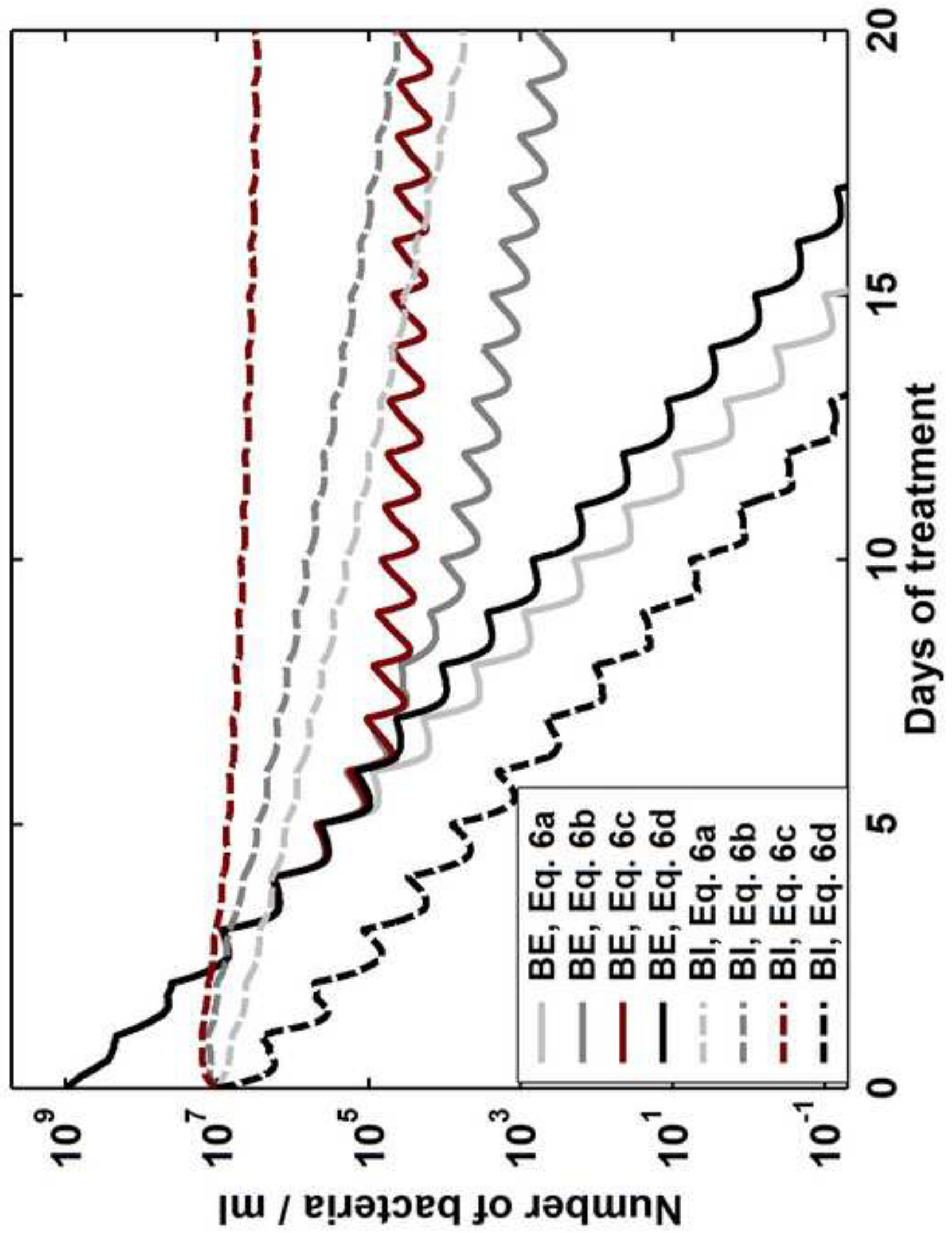




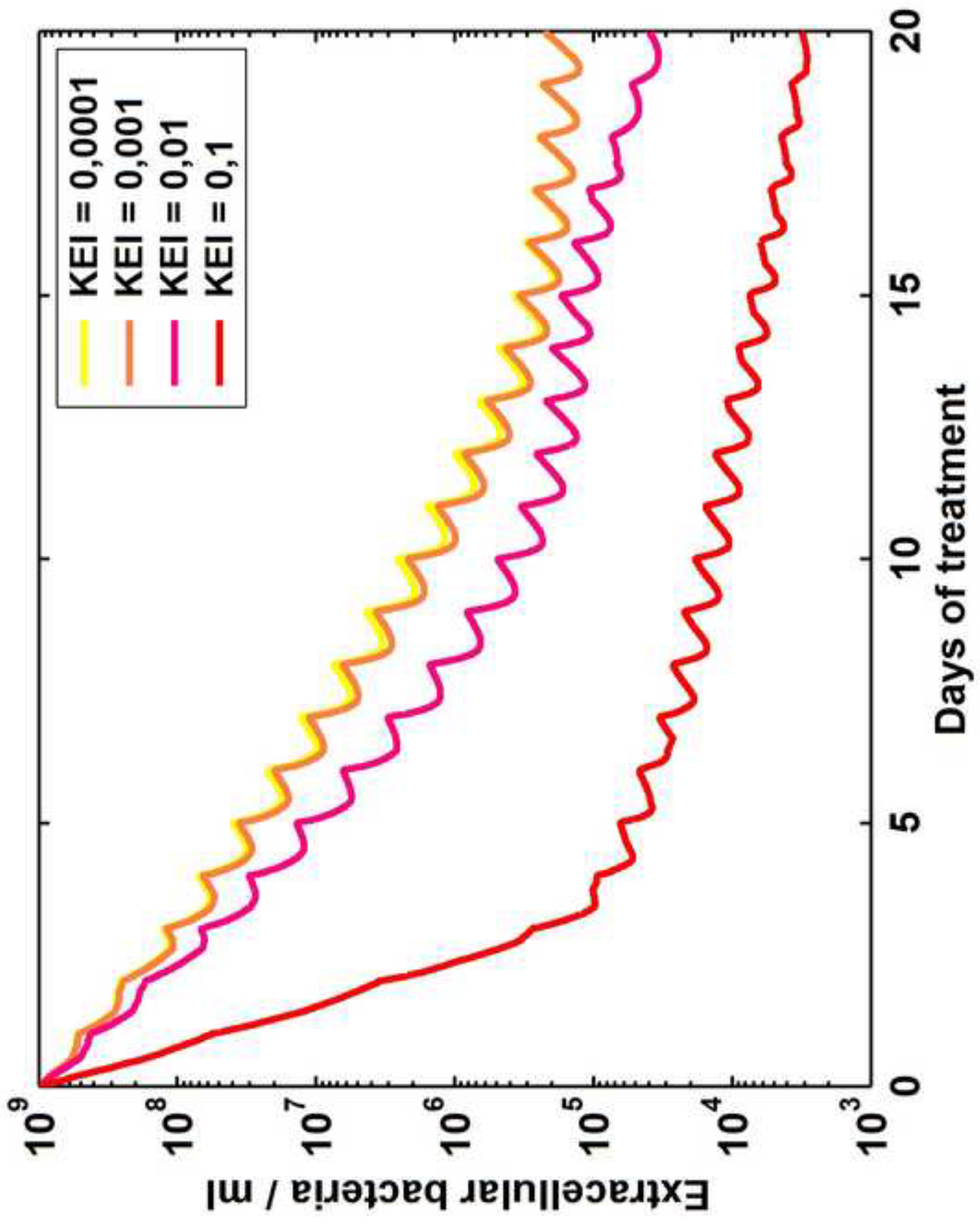




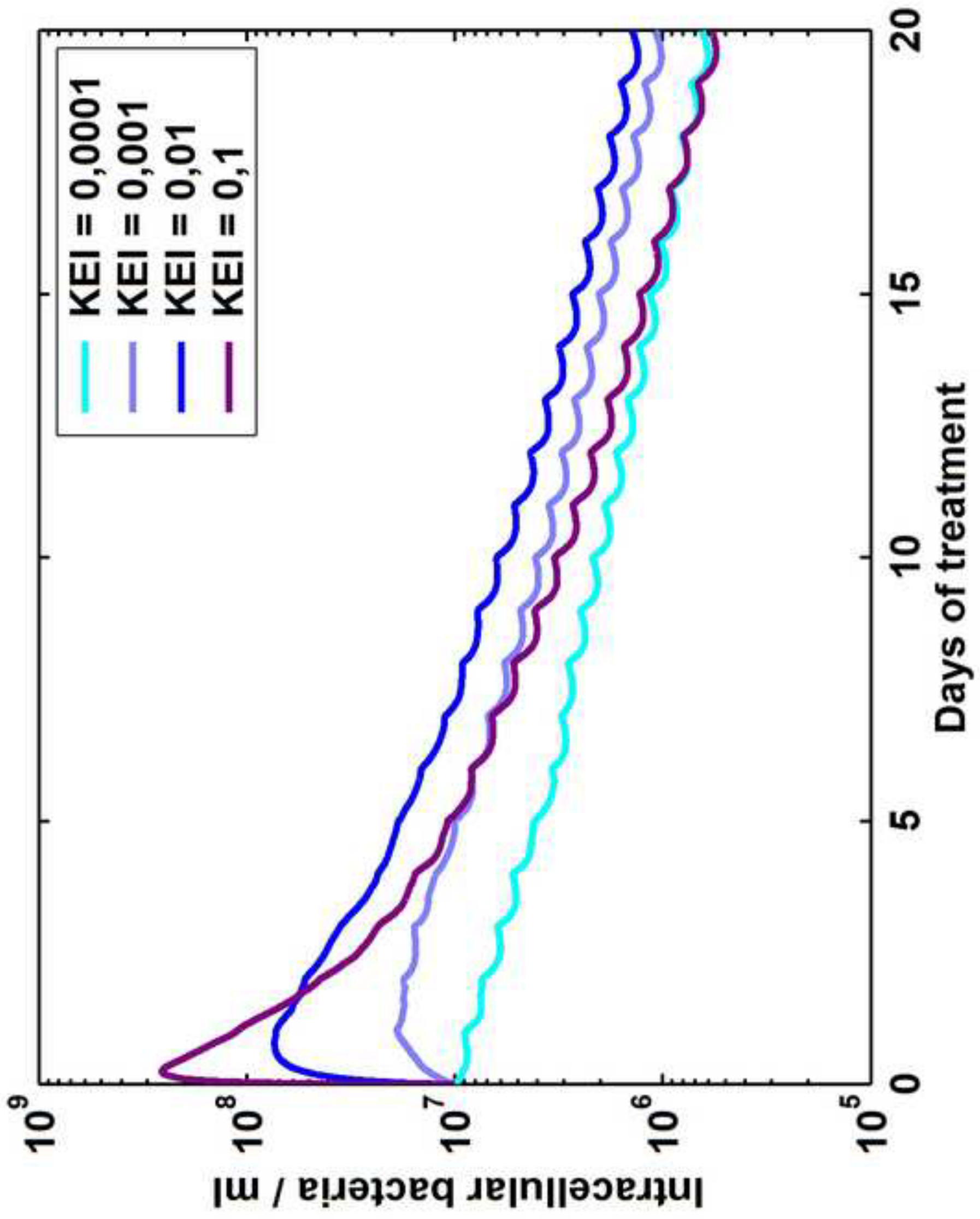




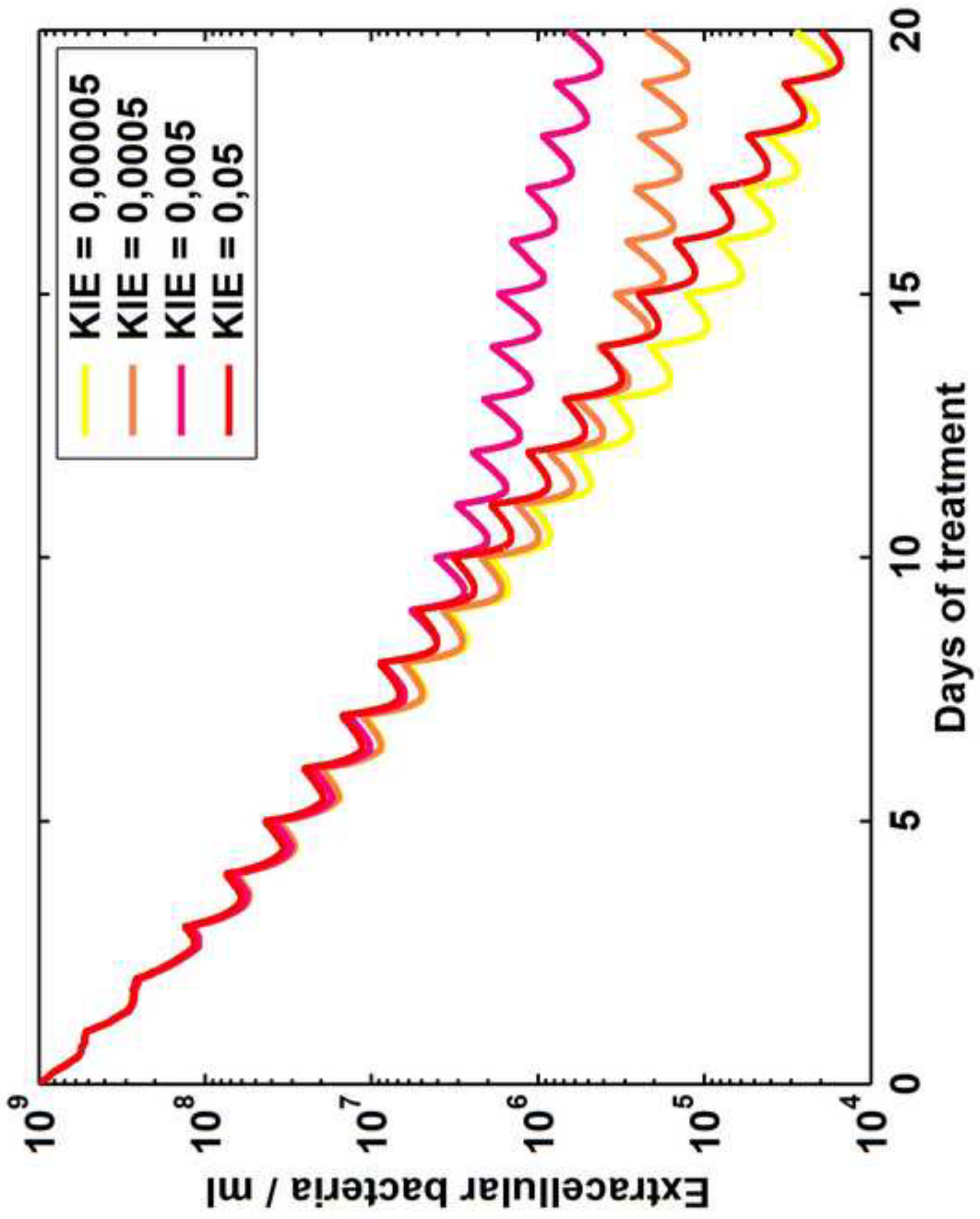




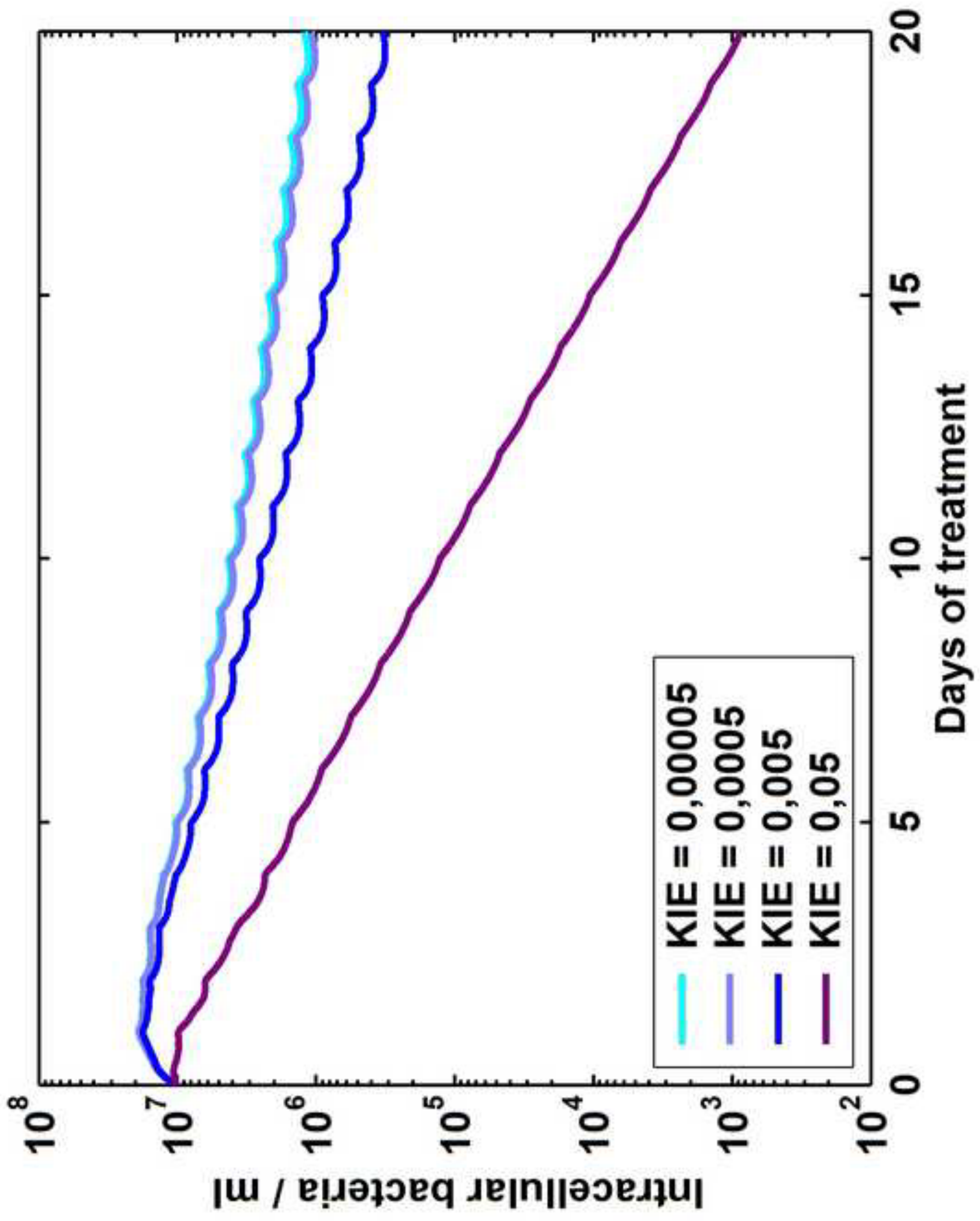




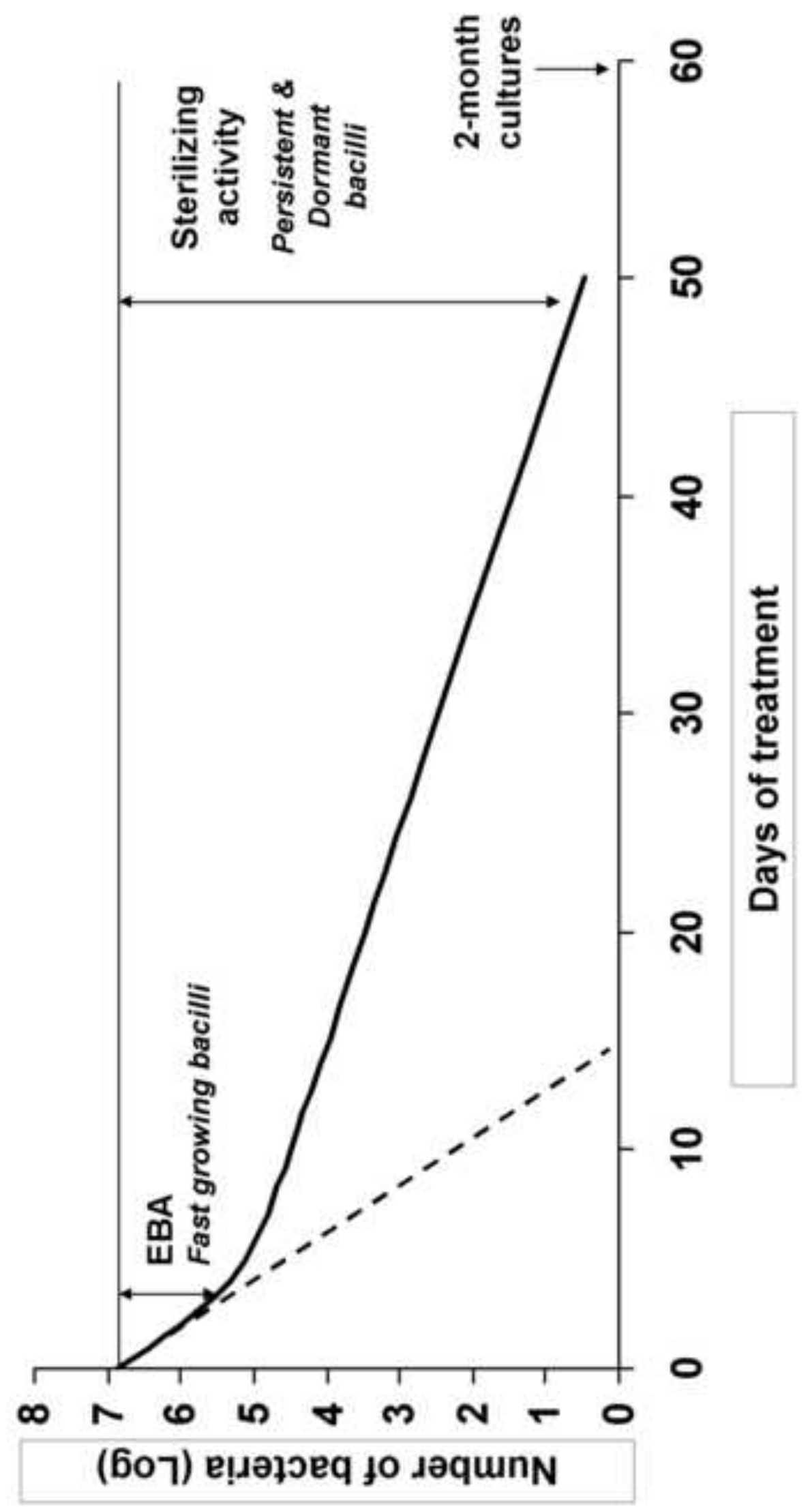

는
은
+ 